Angelina Raičković

UDK 904:739.2"652"(497.11)

Archaeological Institute, Belgrade

$902.2(497.11)$

araickovic@yahoo.com

Original research article

Bebina Milovanović

Archaeological Institute, Belgrade

Received: June 03, 2010

Accepted: August 02, 2010

\title{
DEVELOPMENT AND CHANGES IN ROMAN FASHION SHOWCASE VIMINACIUM
}

\begin{abstract}
Long-term researchs on Viminacium provide ample findings according which we can follow the fashion trends of the Roman Empire. We provide the best picture performance from the coins, and needles, combs and beauty accessories speak to the fact that the Viminacium took account of the appearance. Discovered sculptures, reliefs and sarcophagi, show what clothes people were wearing then, and the attachments in the graves, and what jewelry had been used.
\end{abstract}

Key words: Viminacium, coins, hair pins, hair styles, sculpture, fibulae, necklaces, earrings, bracelets, rings.

During the last few decades of the Viminacium excavations, a great number of finds was discovered that indicates that its inhabitants followed "fashion" and paid great attention to their appearance and outfits. Cosmetic plates, bone needles and combs, as well as lead mirrors show the investigators how everyday life of an average Roman citizen looked like. If one adds frescopainted tombs, reliefs on stone sarcophagi, images on coins and high-quality luxurious jewelry, the picture becomes much clearer. Relying on Viminacium finds, this paper represents an attempt to make an overview of development and changes in hair-styling and fashion, as well as to determine which kind of influence the capital of the Empire, Rome, had on the capital of the province of Upper Moesia.

The most numerous material offering information about such changes are silver and bronze coins, because not only Roman emperors depicted on them, but also members of their families. On obverses, there are emperors depicted with their wives, mothers, sisters, brothers, sons and daughters. Pictures of Roman empresses are of special importance for an analysis of hair-styles. They are so precisely depicted, that one can track down changes in hair-styling and wearing, since hair-styles are an inevitable part of fashion. Hair-

* The article results from the project: Viminacium, Roman city and military legion camp - research of material and non material of inhabitants by using the modern technologies of remote detection, geophysics, GIS, digitalisation and $3 D$ visualisation (no 47018), funded by Ministry of Education and Science of the Republic of Serbia. 
styles differ from one period to another, depending on taste and tradition, geographic and social conditions. From early times onwards, people attempted to stress their originality with unusual hair-styles. It is exactly this element of hair-styling on portraits that helps precise dating of mints. By following images on coin obverses, frescos or modelled portraits, one can also determine which hair-style was in at the time. Handcraft and artistic expression were on a high level. The spirit of time and the look of a lady was reflected in them. Artists managed to depict the simpliest hair-styles, but also the most complicated ones. An empress or not, an average woman spent a long time doing her hair. There were hair-dressers (ornator or ornatrix) working either in their houses as slaves or as independent hair-dressers in their own salons (Lalović 2007). They were able to form three main hair-styles: 1 . hair, freely falling, with curls, 2. hair simply lift into a vertical bun and 3. round bun put in a net (reticulum) on the back of one's head. For all of the hair-styles it was necessary to have thick and shiny hair. Hair growth was impelled by rubbing it with fired donkey's hoof, while it was given shine with liquid soap mixed with different oils. Different combs, hairpins and ribbons were also necessary for hair- styling. During archaeological excavations in Viminacium, over 1,700 bone needles and pins were discovered, as well as 43 combs. ${ }^{1}$ Combs (pecten) were made of bone or wood and some of the examples were richly decorated (site Više grobalja, C-1229) (Fig. 1. and 2.). The simpliest models were single jagged, while the most frequent were double jagged, one side being more dense than the other. The less dense side was used for combing and the other one for hair-modelling. Sometmes they were also used for lifting hair. Pins that were discovered were used for separating locks, making parts and holding hair. They were usually made of bone or horn (acra discriminalis). Pins with sim-

1 It needs to be stressed that research of the city only began, while before only Viminacium cemeteries were investigated.

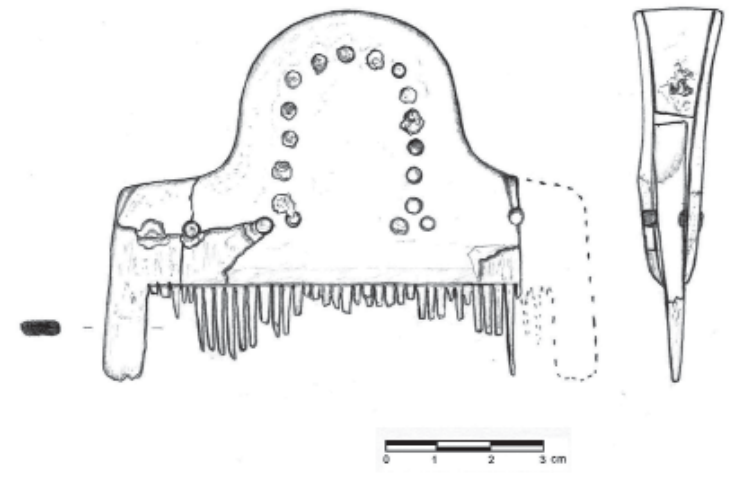

Fig. 1. Drawing of a comb, site Amfiteatar C-1465

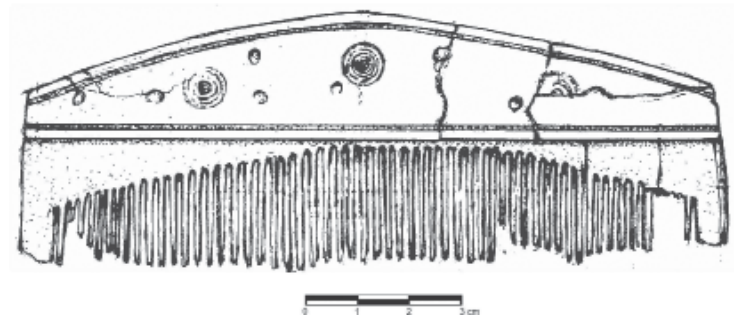

Fig. 2. Drawing of a comb, site Amfiteatar C-1229

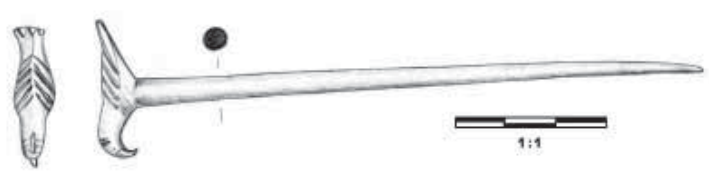

Fig. 3. Drawing of a needle, site Kod koraba C-446

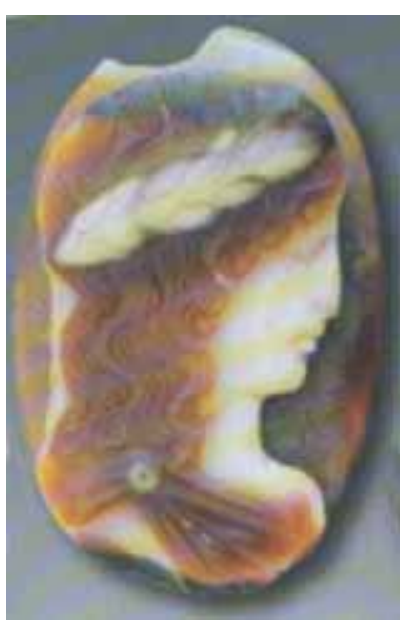

Fig. 4. Photo with a cameo, (Spasić - Đurić, 2002: 92) 


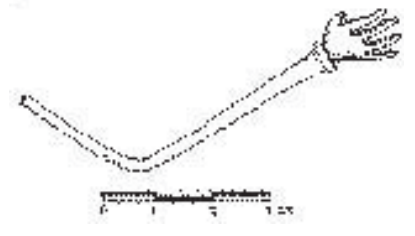

Fig. 5. Metal needle, site Pećine C-684

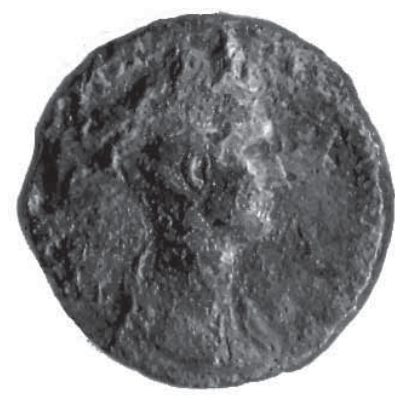

Fig. 6. Sabina, site Više grobalja C-10004, ref. RIC II 1023

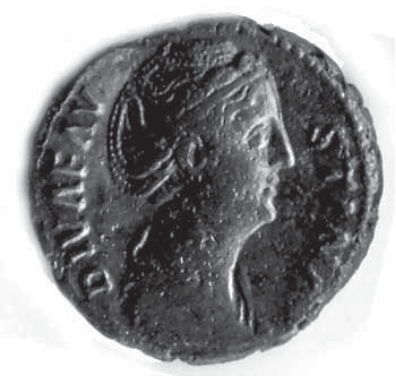

Fig. 7. Faustina Senior, site Više grobalja C-5269, ref. RIC III 1187

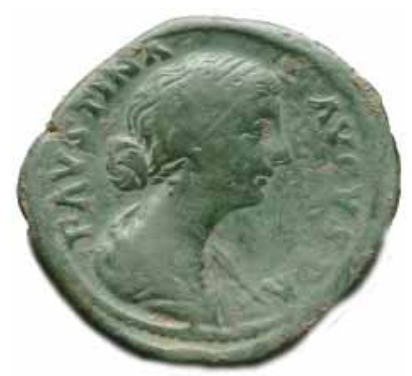

Fig. 8. Faustina Junior, lok. Više grobalja C-3298, ref. RIC III 1389a ply decorated heads were used for twisting and curling hair (acus discerniculum), while the richly decorated ones were used as hairpins (acus crinalic, comatoria, crinale). (Fig. 3.) Apart from bone and wood, they were also made of metals: bronze, silver and gold (site Amfiteatar 2011, C-3030).

On Roman republican silver coins found at Viminacium (sites Kod Koraba, Na Humci etc.) one can tell that men previously wore long hair and only later it became fashion to wear short hair. Young girls wore smoothly combed hair down to their necks and bound with ribbons and pins, or formed into a braid or a bun. Married Roman women wore their hair lifted into a hairdo named tutulus. During this period, hair-styles were simple, since hair was tied at the back of one's head with ribbons and pins - hair-pins or formed into a braid out of which a bun was made. Sometimes, thin locks were left, falling slightly over the forehead. On a trifoil ellyptic cameo found in Viminacium, a woman whose face is framed with spiral locks is depicted, while she wears a laurel wreath on her head. According to a characteristic profile and the way of combing, the picture on this cameo was determined as a portrait of Agrippina the Elder (Srejović 1987: 162). (Fig. 4.) At the beginning of the Imperial age, hair-styles were simple. Hair is of middle length, part is in the middle and hair falls symetrically around the face, with a lock or two, ending with buns or braids. Such hair-styles were worn by Livia (Sear 1974: 89/447; RIC I: 46) ${ }^{2}$ and Octavia, Augustus' wife and sister. Later on, hair-styles become much more complex and even hair inserts were added. For fixing such inserts, bronze or bone pins were used, decorated on both ends. (Fig. 5.) Inserts or complete wigs were made out of slaves' hair and were available in two colours: blond and black. It was also possible to dye hair using different mixtures of plants and ashes. Such hairdos were voluminous, made even more outstriking when pins, flowers, wreaths etc. were added. They were usually worn by matrons at the court and during festivals.

Extreme and complex hair-styles, becoming fashionable in 1st century A.D., consisted of curls arranged on forehead, thus forming voluminous appearance of the whole hairdo. Different pins, flowers, wreaths and diadems contribute to even greater voluminosity. On extremely rare golden aurei ${ }^{3}$, the empress Martiana died in 114 (Sear 1974: 133/966), sister of emperor Trajan (Markus

2 At Viminacium site Više grobalja, C-1121, ob. IVSTITIA.

3 Numerous coins (mostly made of bronze and silver) with images of empresses discovered at Viminacijum are poorly preserved, so apart from them and their readings, photographs of coins on which the hair-stylings are clearly visible are given in this paper. 
Ulpius Traianus, 98-117), was depicted with high lifted hair and a wreath above her forehead. The same hair-style is shown on the portraits of Sabina ${ }^{4}$ died in 136 (RIC II: 1023), the wife of the emperor Hadrian (Publius Aeilus Trajanus Hadrianus, 117-138). This style shows many variations (Fig. 6.). Apart from simply cotted hair, hairdos decorated with diadems or veils were very common. Faustina Senior, died in 141 (RIC III: 1187), ${ }^{5}$ the wife of Antoninus Pius (Titus Aurelius Fulvus Boionius Arrius Antoninus, 138-161) was well-known because of her beauty and wisdom. (Fig. 7.) When her husband was enthroned, she became an "Augusta", and on the mints from that period, she was depicted as a middle-aged woman. Numerous coins with her portraits depict her with high combed hair, decorated with pearls tied into a wreath, but sometimes also with hair covered with a veil. Coins with her image, both with and without a veil, are the most numerous ones at Viminacium. In 145, the daughter of Faustina Senior, Faustina Junior died in 175, (RIC III: 1389/a) $)^{6}$, married the young emperor Marcus Aurelius (Marcus Aurelius Antoninus Augustus, 161-180) (Fig. 8.). She was very similar to her mother and well-known for her beauty. On coins, she was depicted as a younger woman, with her hair always tied in a bun. Instead of a diadem, her wavy hair was divided with a braid. The same hairdo, hair divided into numerous small braids, all tied in a bun at the back of the head, was also worn by her elder daughter Lucilla (RIC III: 1752 and 1743) (Fig. 9.).This can be seen on numerous coins discovered at Viminacium cemeteries. Comodus (Lucius Aelius Aurelius Commodus 177-192) wife, Crispina ${ }^{8}$ (RIC III: 672a) (Fig. 10.) also liked this hair-style. The names and images of the empress Manillia died in 193 (Sear 1974: 174/1614) and her daughter Didia Clara (Sear 1974: 175/1621) are known to history only from a small number of coins, minted during the sixty days of her husband Didius Iulianus' rule in Rome in 193 (Marcus Didius Julianus 193). On a golden coin, her bust was depicted with her hair tied in a big bun, which separates her from other empresses. During the first half of $3^{\text {rd }}$ century, Iulia Domna died

4 Site Više grobalja, C-4805, 5389, 6407, 6436, 10004, ob. [SABINAAVGVSTA HADR]IANI AV[GPP].

5 Site Pirivoj, C-274, 584; Na kamenju, C-71; Na Klepečkoj, C-66, 81, 363, 366. Site Više grobalja, C-2862, 2888, 2969, 3083, 5269, ob. DIVA[F]AVSTINA.

6 Site Pirivoj, C-363; Na kamenju, C- 61; Na Klepečkoj, C-663; Više grobalja, C-2495, 2666, 3793, 3928, ob. FAVS[TINAA]VG[VSTA].

7 Site Više grobalja, C-479, 1575, 1653, 1948, 3456, 4752, 9390, 12268, ob. LVCILLA AVGVSTA.

8 Site Više grobalja, C-1996, 4701, 5218, 8839, 11642, 12637, ob. CRISPINA AVG[VST]A.

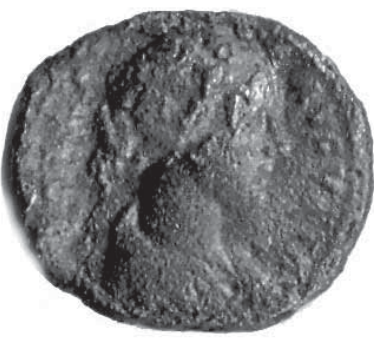

Fig. 9. Lucilla, site Više grobalja C-12268, ref. RICIII 1752

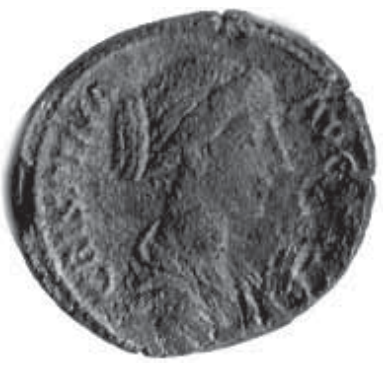

Fig. 10. Crispina, site Više grobalja C-12637, ref. RIC III 672a

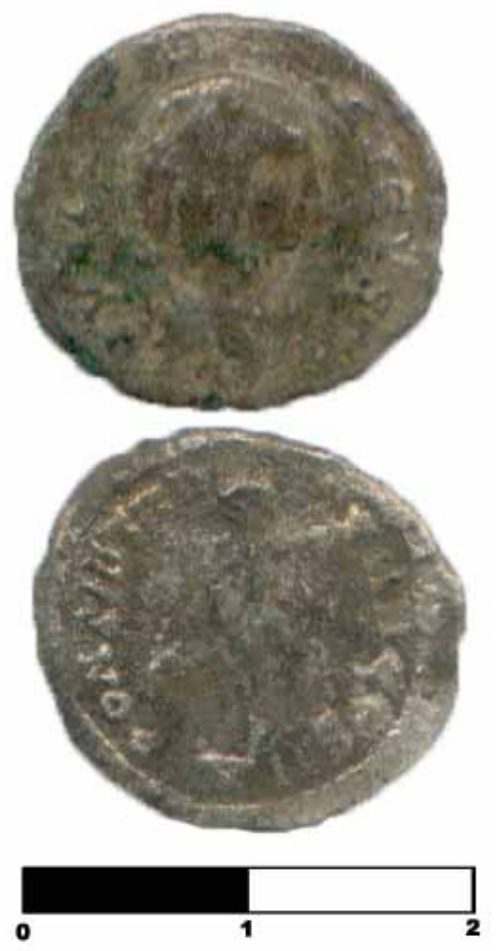

Fig. 11. Iulija Domna, site Više grobalja C-8825, ref. RIC IV 1.527 

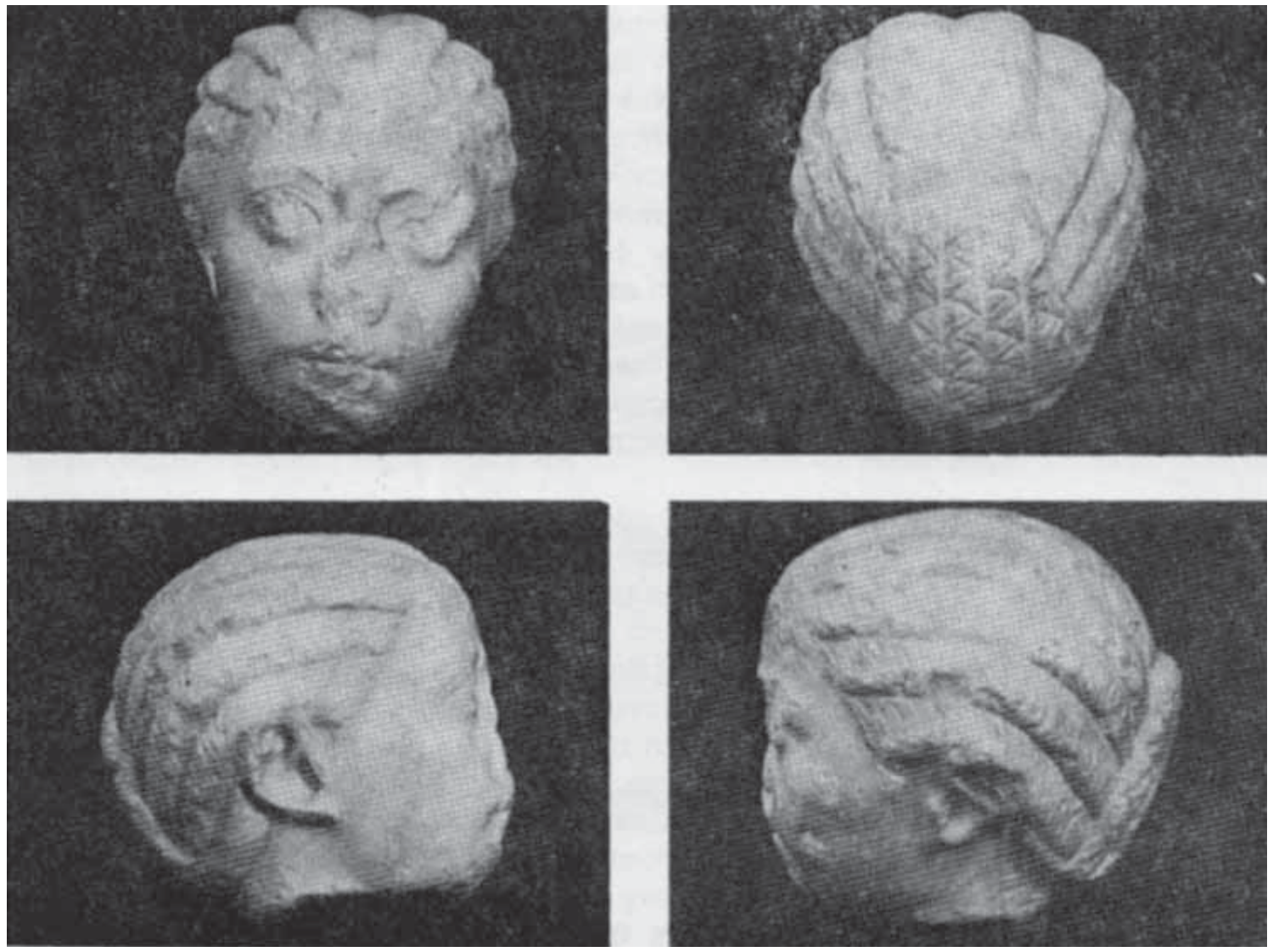

Fig. 12. Portrait of Plautilla's head, Viminacium

in 217 (RIC IV: $1.572 ; 1.574 ; 1.536)^{9}$ (Fig. 11.), the wife of the emperor Septimius Severus ( $\mathrm{Lu}$ cius Septimius Severus 193-211), introduced new fashion in hair-styling, as well as new customs in court. She did not originate from Rome, but from the town of Emes in Syria. She was a daughter of Bassianus, the priest of the sun, which can clearly

9 Site Pirivoj, C-66; Nad Klepečkom, C-222; Više grobalja, C-262,678, 8825, ob. [IVLIA AVG]VSTA.

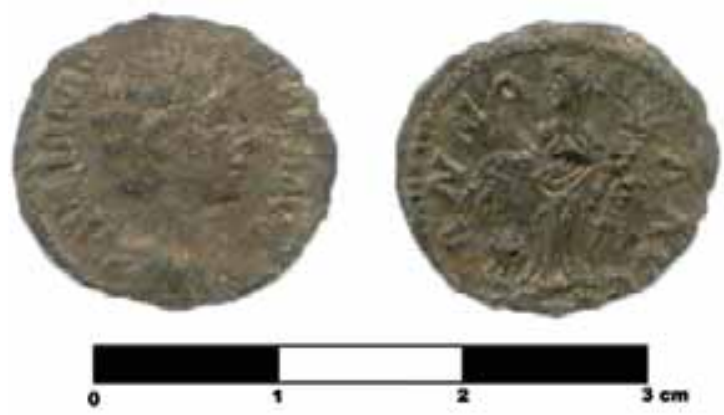

Fig. 13. Iulija Mamea, site Više grobalja C-9816, ref. RIC IV 2.341 be seen on her portraits and especially reflected in her unusual hair-style. Long, voluminous hair is divided in the middle, freely falling down the shoulders and then combed backwards. There are over 300 different portraits of her, either on coins or carved in stone. Among coins with pictures of empresses, her coins are the most numerous in Viminacium. Iulia also had a sister, Iulia Maesa (Sear 1974: 206/2089) a very powerful woman, who had strong influence on her daughters' marriages to Roman emperors. From the end of 2nd and during 3rd century, it was considered noble to frame one's face with slightly wavy hair. The rest of the hair was tied into a bun or braid, made in the shape of a diadem and twisted around one's head. A portrait of a young woman, discovered in Viminacium, shows a typical hairdo with hair formed in melon-slice-like parts and therefore named "melon" (Fig. 12.). The "melon-slices" are tied in a bun at the back of her head, while 


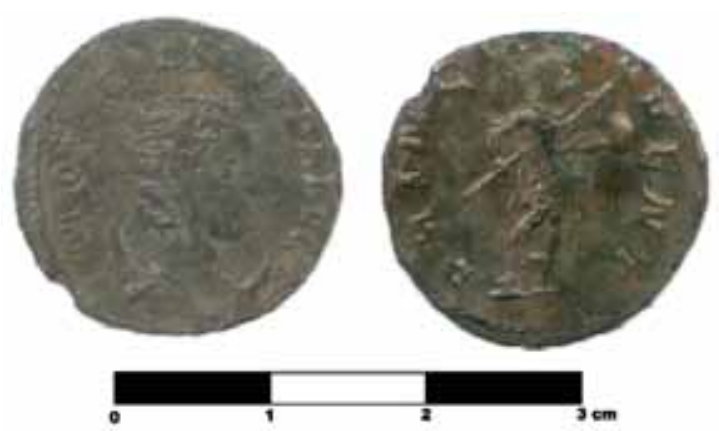

Fig. 14. Otacilla, site Pirivoj C-234

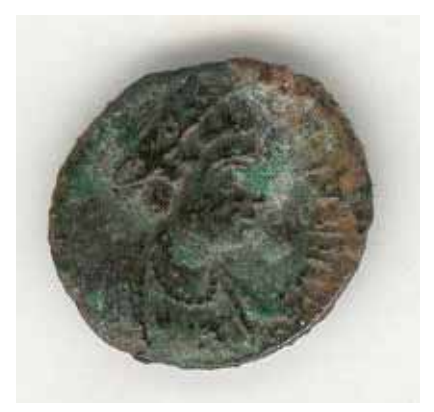

Fig. 15. Helena, lok. Kod Koraba C-459 short wavy locks were depicted in shallow relief and left infront of her ears. For a long time, such hair-styles were worn by unmaried girls. The head is damaged (Tomović 1986: 31-32), but it can be supposed who was depicted. An identical portrait was discovered in Solin (Cambi 1987: 74 and 76), and although there are no closer data about its discovery, it was dated at the beginning of 3rd century. After analogue depictions on coins, this portrait was ascribed to Plautilla Fulvia (Buzov 2008: 473-488), Caracalla's (Lucius Septimius Bassianus 211-217) wife. He was nick-named after a Gaulish tunic, which he introduced to the Roman fashion. It is known that Caracalla visited Viminacium on two occassions, but it is also known that he did not love his lawful wife. She was murdered after his order and was condemned to damnatio memorie, meaning that every memory of her had to be destroyed. Only from 202 did her images appeared on coins, and in January 205 Caracalla divorced and expelled her. Her portraits are found on some of the coins from the Viminacium cemeteries (RIC IV: 1.366). ${ }^{10}$ Iulia Maesa (RIC IV: $2.272 ; 2.268 ; 2.249)^{11}$ had a daughter Iulia Mammea (RIC IV: 2.358; 2.351; 2.347; 2.341) ${ }^{12}$ (Fig. 13), who was depictd on well-preserved sestercii found on several sites in Viminacium. Therefore, we were able to conclude that up to the thirties of 3rd century, a low diadem formed of hair divided into locks was in fashion again, also worn by Alexandar Severus' wife Orbiana (Sear 1974: 213/2202).

On one of the sites, Pirivoj, a silver Antoninianus with Otacilla's portrait was discovered at site Pirivoj (C-234) (Fig. 14.), the wife of the emperor Philipp I, (Marcus Julius Philippus 244-

10 Site Više grobalja, C - 8989, ob. [...]П $А A V T I \Lambda \Lambda A$ CEB; C- 8323 ob. PLA[VTILLAE] AVGVSTAE.

11 Site Više grobalja, C-423, 679, 8643 ob. [IVL]IA MAESA [AVG] .

12 Site Pirivoj, C-321, 695; Nad Klepečkom, C- 416; Više grobalja, C-2849, ob. IOY $\Lambda$ IA MAMAIA AVГ, BMS 105; C-4, 8837, 7345, 9186 ob. [IVLIA MA]MAEA.

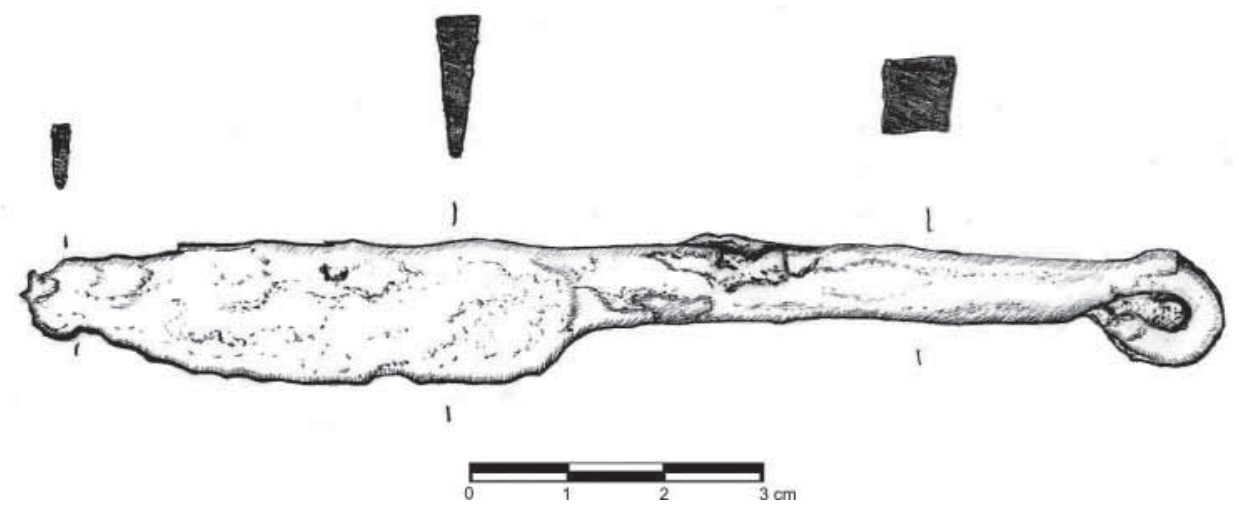

Fig. 17. Rasor, site Pirivoj C-593 


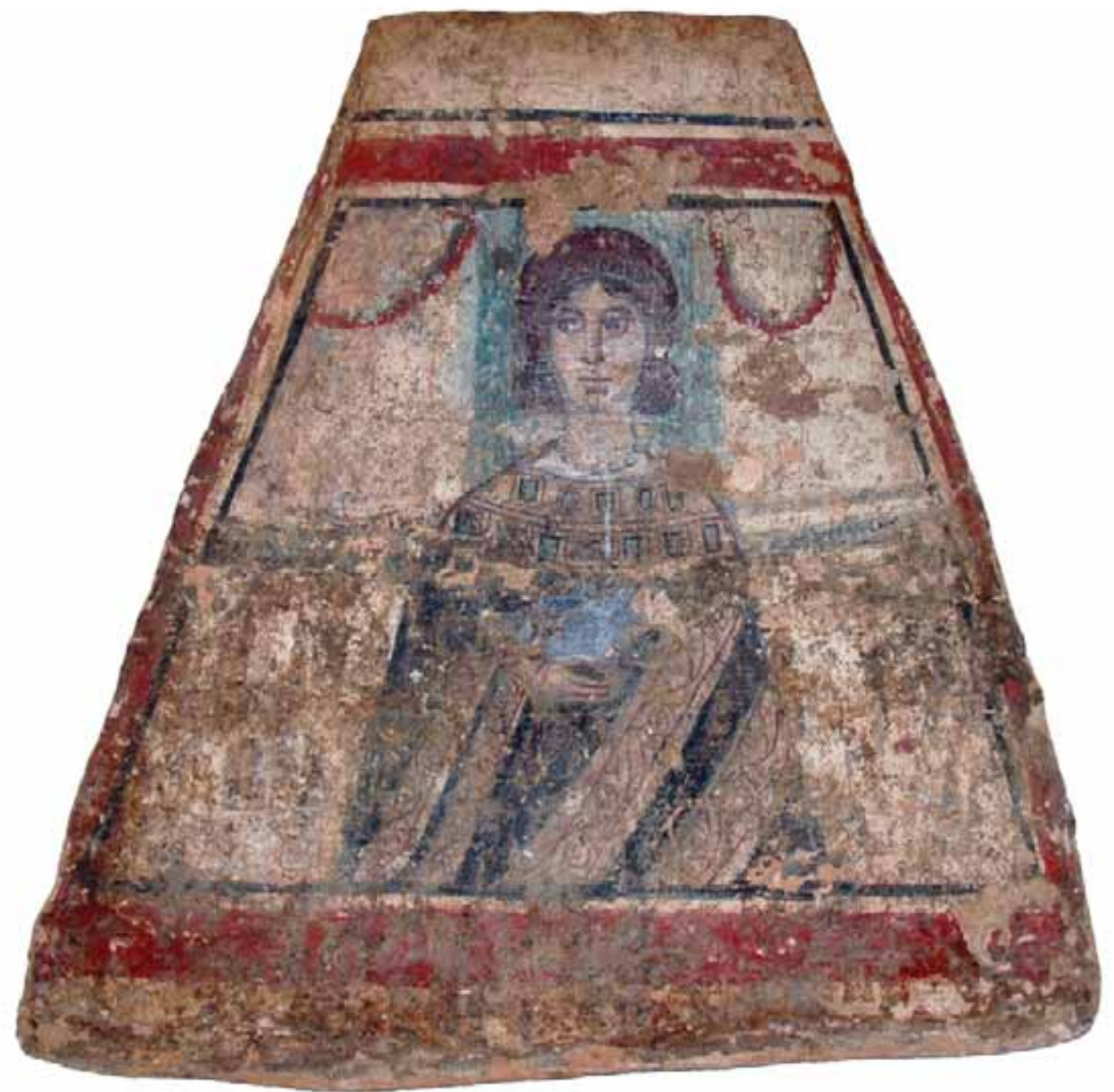

Fig. 16 Fresco with a girl

249). She was usually depicted as a younger or an elderly woman, with her hair traditionally divided into horizontal braids reaching her neck and then lifted to the back of her head. During the sixties of 3rd century, Salonina (RIC V: 1.5), Gallienus (Publius Licinius Egnatius 253-260) wife, wore the same hair-style, with her whole hair divided into small braids lifted to the back of her head, while there is a low diadem on her head as well. Such hair-styles are encountered on Viminacium coins up to the time of the empress Galeria Valeria died in 315 (Sear 1974: 304/363), the daughter Diokletianus' (Gaius Aurelius Valerius Diocletianus 284-305) and the wife of Galerius Maximianus (Gaius Galerius Valerius Maximianus
305-311). On coins, she was depicted as a young woman with straight combed hair and a small diadem decorating her head. From that period there is also a silver coin with the image of Constantine's first wife Helen $^{13}$ (Fig. 15.) and a fresco-painted tomb from Viminacium (site Pećine, G-2624), in which a portrait of a young woman with oval face, big eyes and long neck was discovered. Her brown hair is falling down to her chin and combed backwards, with a net over it (Korać 2007: 104). (Fig. 16.)

Men paid much less attention to thier hairstyles. Some had their personal barbers (tonsores), some went to barber-shops, but no-one shaved on

13 Site Pirivoj, C-472; Kod Koraba, C-459. 
his own. They spent much time in such places, because of great numbers of customers and companions who gathered there, but also because of the shaving process itself, which was long and rather painful. It was done with iron or bronze blades (novacula) sharpened with whetstones. Blades were either with fixed handles (site Pirivoj, C-593; Rit, C-15), or with a flexible handle (Fig. 17.), but in both cases the procedure was long and unpleasant, because the skin was wettened only with water and it often led to cuts. Bleeding was stopped with a bundle of spider's web soaked into oil and vinegar. In order to avoid painful and long shavings, men rubbed themselves with resins, mixture of white grape-vine, ivy liquid or, in drastical cases, bat's blood. There was also a way to cover scars using small textile bundles. Most of men were probably relieved when emperor Hadrian introduced wearing beards, because he himself wanted to hide scars on his face. Much attention was paid to beards, which can also be recognized in a festival organized for young men and their first shaving (Petronije: 45). Fashion in beard-wearing can also be followed owing to depictions on coins. One can tell that beards were differently stylized for a century and then they were again replaced with smoothly shaved male faces. Hair cutting was done with scisiors ${ }^{14}$ (forfex), consisting of a pair of blades conected with joints or with a simple bow-mechanism (Fig. 18.). Hair-cutting with such scissors was rather uneven. In order to make uneven cuts less visible, hair was curled with an iron bar warmed up in live coals. Such a treatment was conducted on men with thin hair who wanted to make it more voluminous. The simpliest male hair-style was named after emperor Titus (Titus Flavius Vespasianus 79-81). Hair was combed from a point on top of one's head towards forehead, ears and neck. There were, of course, more intriguing hairdos, consisting of rows of curls spread in different ways and fram-

14 Found at some of the sites: Više grobalja, C-960, 1286, 1296; Nad Klepečkom, C-974; Lugovi, C-14.

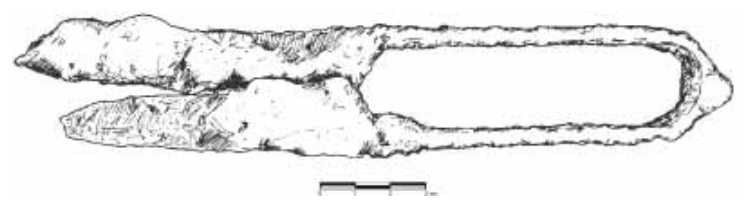

Fig. 18. Scissors, site Više grobalja C-1286

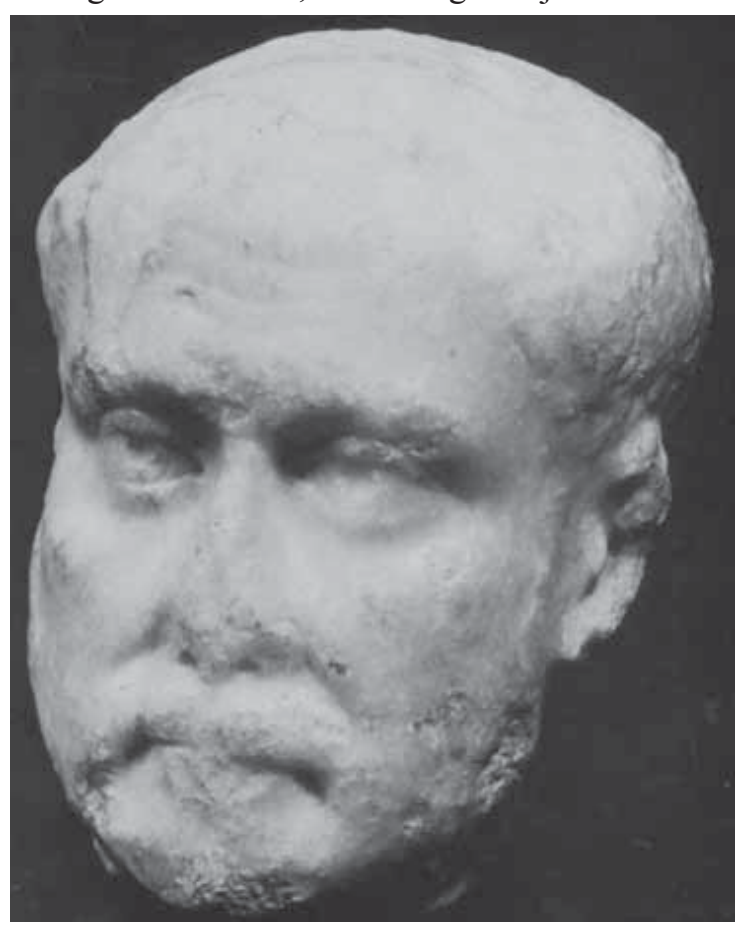

Fig. 19. Man's head, Viminacium

ing one's face. Several sculptures were discovered in Viminacium (Tomović 1986: 31-39). One of them shows a man with a high forehead, sideburns and wrinkles. His hair and beard were done in locks. His eyes are outstriking, while his beard is of decorative character. According to its style, this portrait can be dated in the middle of 3rd century, while it is believed that it was made in one of the better provincial workshops. (Fig. 19.) In a cameo made of two-coloured onyx a man is depicted, with smoothly shaved face and outstriking lips. His short hair frames his face, leaving one ear visible. The hair is depicted in the form of small rectangles, resembling a honeycomb. The man wears a cloak with edges around his neck done in relief. According to its characteristics, this cameo can be dated into the period of early tetrarchy, around 300 A.D. (Srejović 1987: 239/232). 

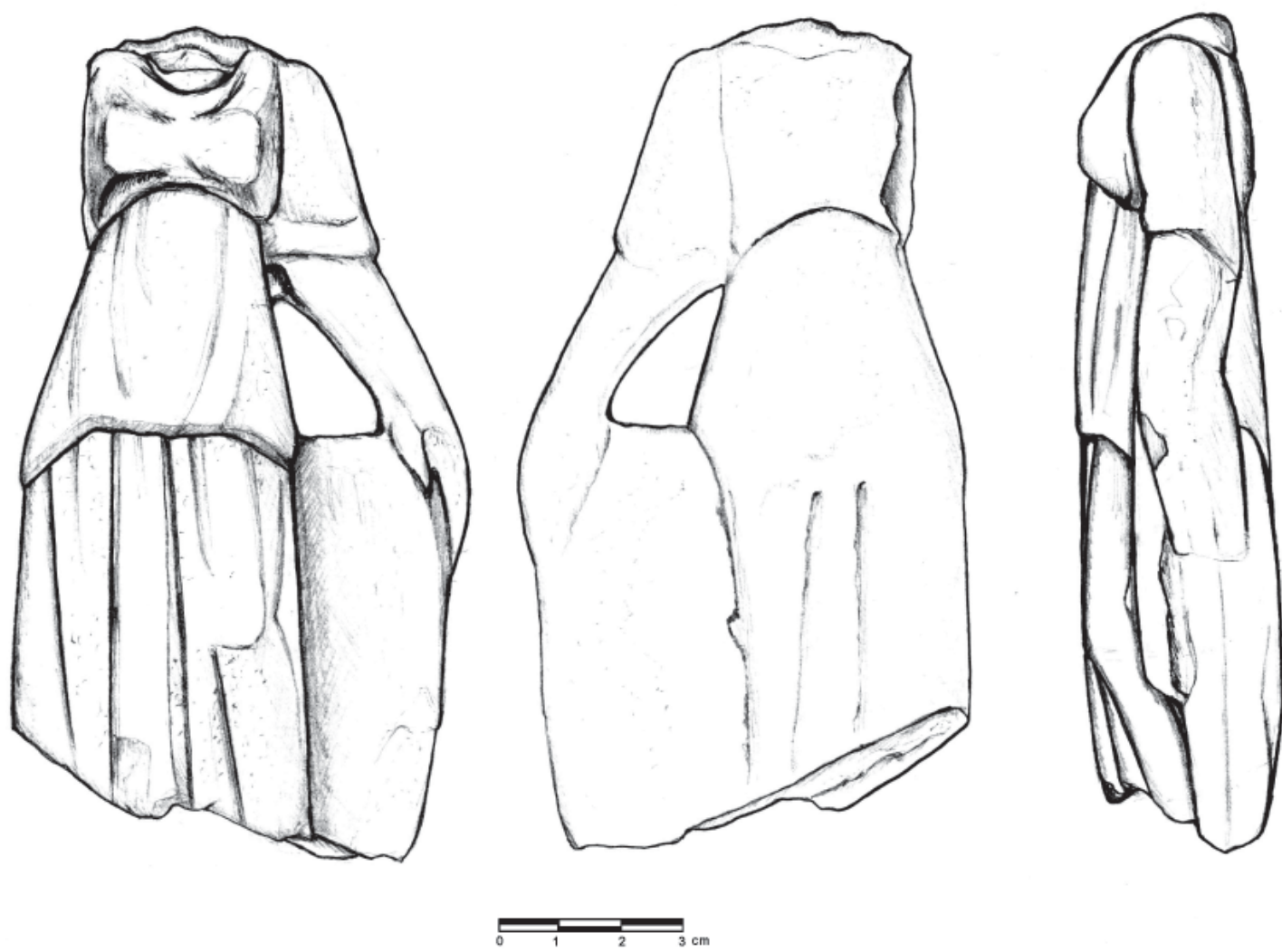

Fig. 20. Terracotta of a female statue, site Amfiteatar C-430

After doing her hair, a woman needed to choose what to wear. Apart from underwear, consisting of a pair of clothes tied around her waist (subligaculum) and a ribbon for holding and fastening her breast (strophium), the main part of woman's clothing was a tunic (Beatson 2004). Tunic is a dress made out of a rectangular piece of textile, fastened at the ends and thus forming short sleeves. There were two kinds of tunics, both overtaken from Greek fashion. One of them was a peplos, made out of two rectangular pieces of textile and sawn at the tops, leaving openings for the arms and the head. It is fastened on the shoulders with ribbons and pins, thus forming sleeves. A more commonly worn kind of female tunic was similar to a Greek chyton. Two pieces of textile were also sawn together and pulled over one's head. A belt was tied either high or low and by combining it, several models of the same dress were obtained (Schneider 2005). Tunics were of differet colours and textile types, depending on social status and wealth. A decorated stola was worn over the tunic, reaching down to the ankles. Over the stola, a long scarf (palla) was worn, which was wrapped around one's body, while one ending could have been put over one's head. If they were about to take part in a religious feast, matrons covered their heads with a rectangular scarf made out of purple or blue textiles decorated with fringes. Among the terracottas discovered during the excavations in Viminacium, one often comes across figures of young women ascribet to female deities. Apart from them, statues of young women were found, dressed in long dresses and with sandals on their feet, which, along with other finds, belong to the middle of 3rd century (site Amfiteatar, C-430, 518) (Fig. 20.). As the power of the Empire grew, more and more luxurious clothes were used, imported from the newly conquered provinces of the Empire. In some of the written sources there is some iformation that a kilogram of silk was just as valuable as a kilogram 


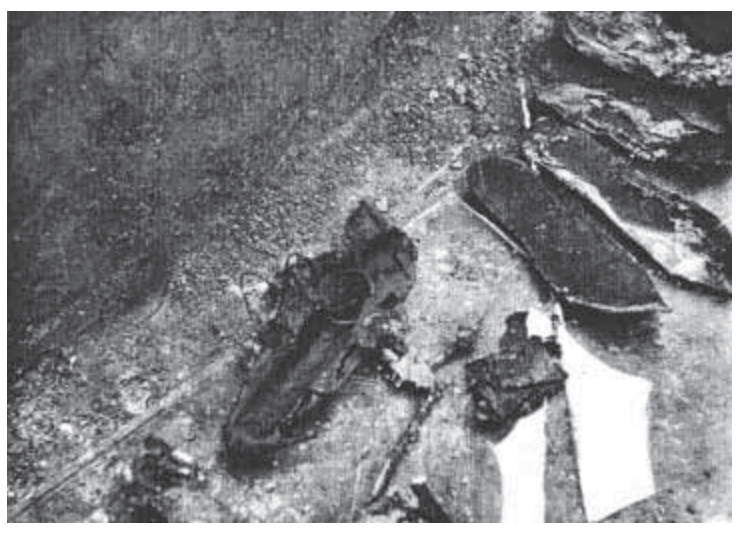

Fig. 21 Photo of shoes, Viminacium

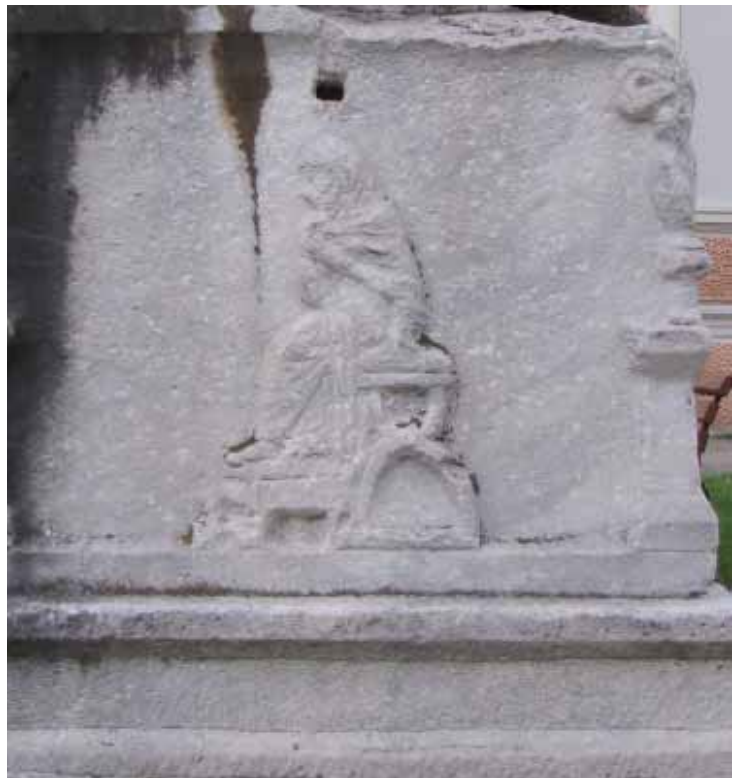

Fig. 22. Sarcophagus from Požarevac, photo by I. Bogdanović

of gold. Not all of the women were as modest as Augustus' wife Livia, who made clothes out of the clothes she personally weaved, so wealthy Roman citizens had difficulties in their attempts to impress their wives or mistresses. Not even Tiberius' (Tiberius Claudius Nero 14-37) decrees were of much help, although tried to make up means of the state treasury caused by exadurated import of luxurious goods. A discovery in the year 1982 of a lead sarcophagus shows that Viminacium women had their share of good taste in choosing textiles and in fashion (site Pećine, G-2047). Skeletal remains of a woman, who wore a linen shirt and over it a dress or a cloak made of purple brocade with golden threads were discovered in it. On her feet, there were socks made out of white cotton and shoes made out of brown leather. Around her feet, there were remains of seven pairs of shoes, all made of brown leather, as well as several soles made of folded cork (Golubović 2000: 83-93). The upper shoes' edges were jagged and decorated with preforations under the edge. The shoes were tied with thin belts. (Fig. 21.) The investigators were able to tell that all of the shoes were of different sizes, which led to a hypothesis that the deceased did not want to dispose some of her favourite footwear even after she grew out of them.

This leads to the question of footwear. Both men and women mostly wore sandals, whose soles were tied aroud ankles with belts. Boots were worn outdoors, reaching up to the calfs and having openings on the sides. They were also tied with belts wrapped around one's calfs. They were mostly made of leather, sometimes decorated with pearls and precious stones. The colour of boots indicated the social status. When people were visiting someone, they brought their sandals with them and put them on, because it was not apropriate to walk inside one's house in outdoor footwear. Deeper boots were designed for hunting and boots with stronger soles for the military. Provincials wore peasant shoes. The poor wrapped their feet into furskins or woolen rags. On one of the frescos there is a young man depicted, carrying plate with offerings, but it can also be seen how young men were dressed. His shoes are especially well shown. During modern excavations, the only remains of footwear found are shoe-nails, and in some cases the whole print of a shoe stamped into clay out of which bricks were made. Apart from the lead sarcophagus, several stone with reliefs were also discovered in Viminacium. On one of them, today in the City Museum of Požarevac, on the lid, a woman with a child is depicted. (Fig. 22.) The same person is depicted on the shorter, lateral side, sitting and moarning. It is considered 


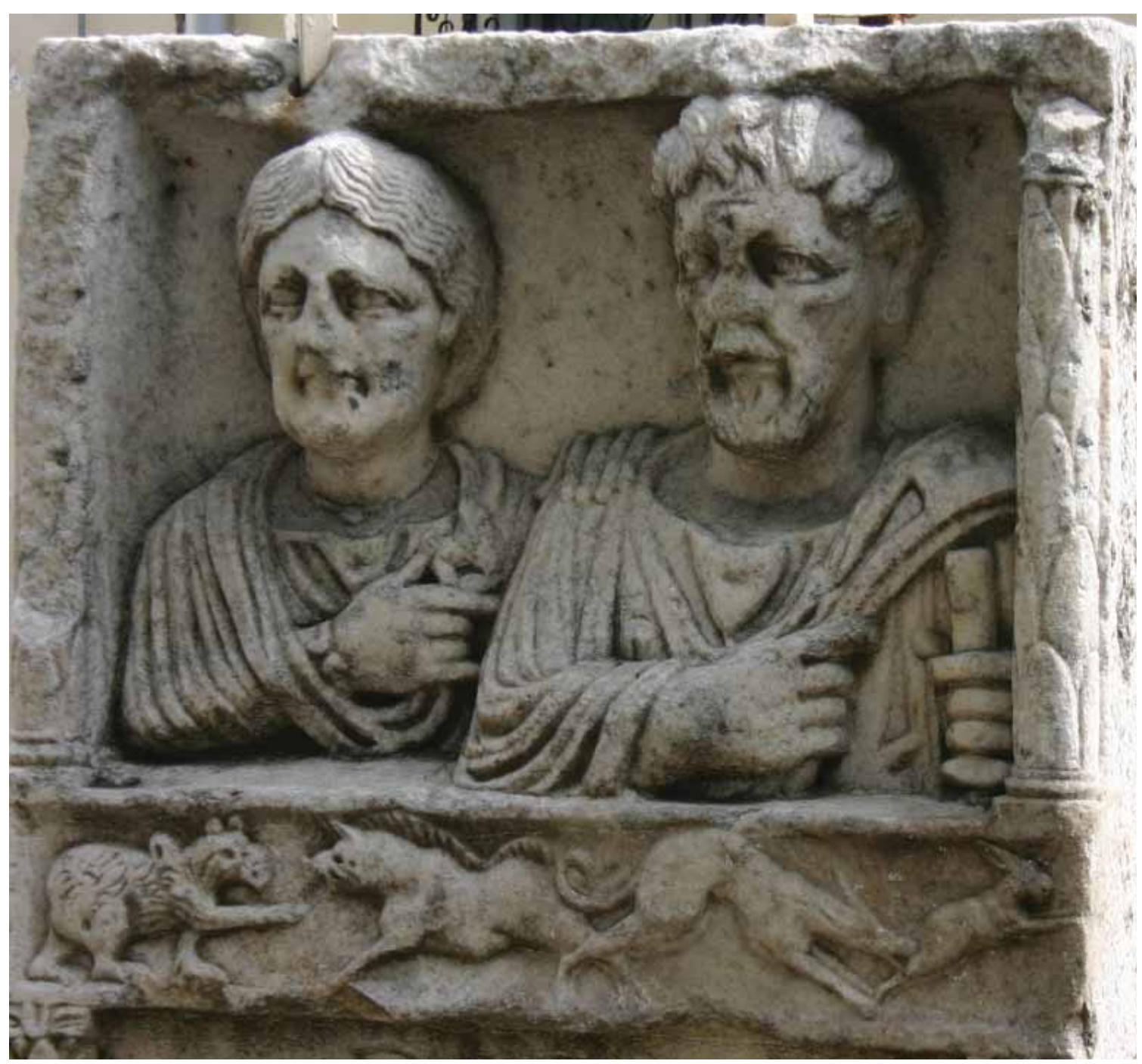

Fig. 23. Funeral stele, photo by N. Mrđić

that the inspiration for such images is to be found on Greek gravestones. The reliefs made on the lateral side and on the lid were added later on in a local workshop (Tomović 1991: 74). According to parallels, the sarcophagus was dated into the second half of 2 nd century. Such pictures of women were also found on some sculptures from Singidunum (Srejović 1987: 227-208). A grave-

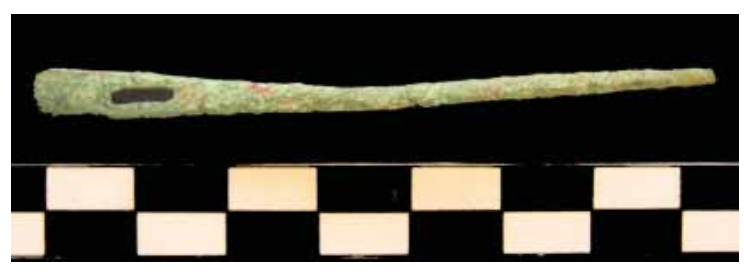

Fig. 24. Sawing needle, site Pirivoj C-77 stone discovered in 1987 at the Viminacium site Pećine (C-12736) bears a relief in its upper part showing a married couple to whom the stele was dedicated. Within the aedicula with portraits there is a woman depicted on the left side, wearing a dress and wrapped into a cloak, while on the right there is a man wearing a tunic with a toga with voluminous folds. In his left hand he holds a roll. Woman's hair is divided in the middle and falling over her ears and then bent low at the back of her head. The stele is dated into the period of the emperor Antoninus Pius (Milovanović, Mrđić 2008) after the jewelry on woman's left and around her neck. (Fig. 23.). 


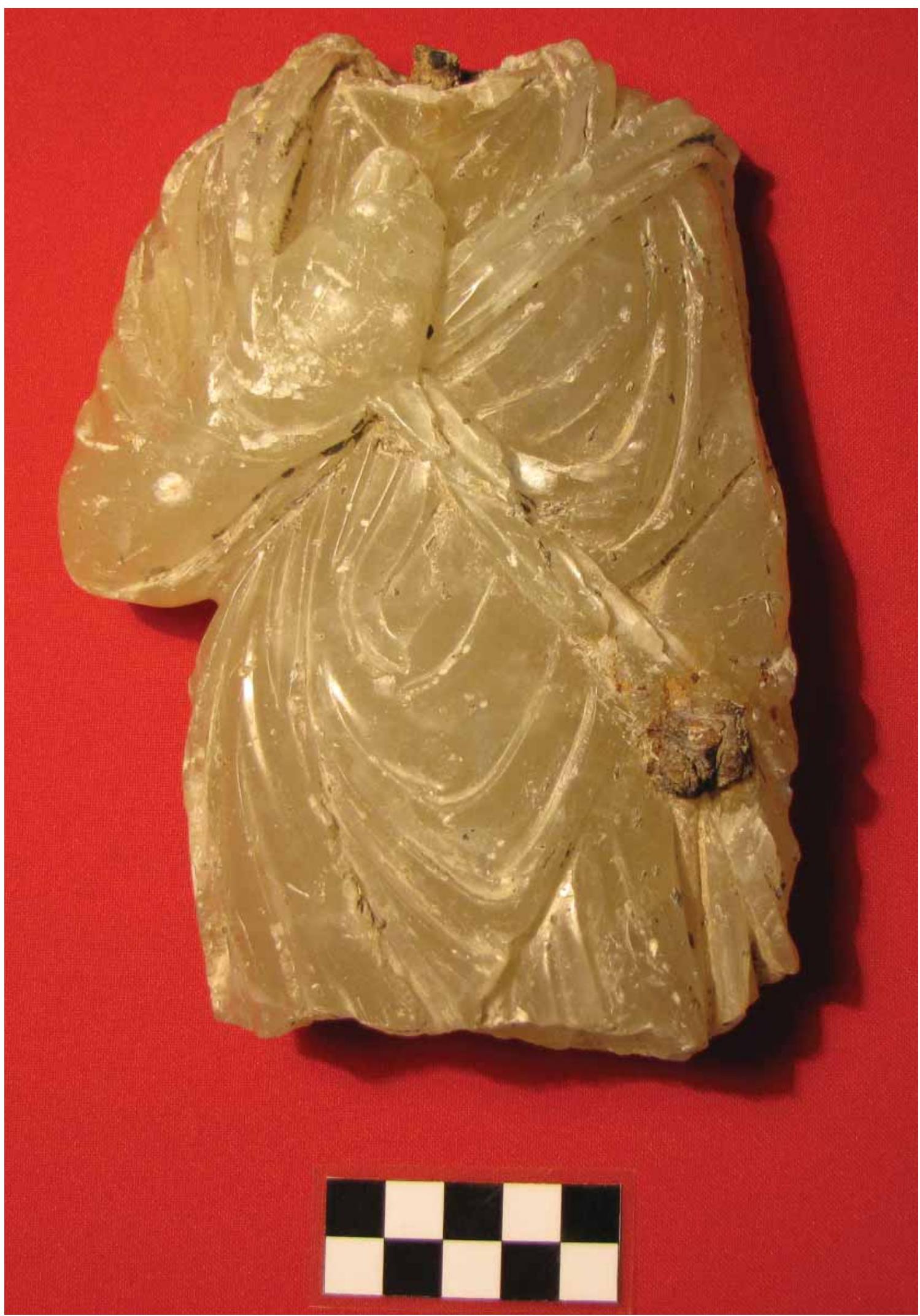

Fig. 25. Quartzite bust, site Amfiteatar C-2499, photo by I. Bogdanović 
Men also had their dressing rites. The Romans mostly wore a tunic and a toga. A classical toga is a special Roman dress worn only by Roman citizens. It was a large cloak made out of almost $9 \mathrm{~m}$ of textile. Since they were voluminous and unpractical, they were soon determined for wearing only on special occasions. During Augustus' time, a moral code existed and togas were worn in all spheres of public life. In time, social traditions changed and various influences came, so the rules were changed. Tunics became more comfortable and covered with a cloak called lacerna, which became common for all kinds of socializings. Not all of the togas looked alike and one was abe to tell the social status of Romans. The most known togas were: virilis, praetexta, pulpa, candida and picta.

No matter what was the piece of clothes, sawing tools were needed for making them (Fig. 24.). On all of the investigated sites, many bone and bronze needles were discovered with perforated heads, thus used for sewing. Their length varies from 4 to $20 \mathrm{~cm}$. One of the sites on which there were many needles discovered is near the Pirivoj necropolis (Raičković, Milovanović 2009: T. XVI-XVII).

Tunic was a short woolen dress with short sleeves. It was worn at home. Members of high class wore tunics made of white wool or expen-

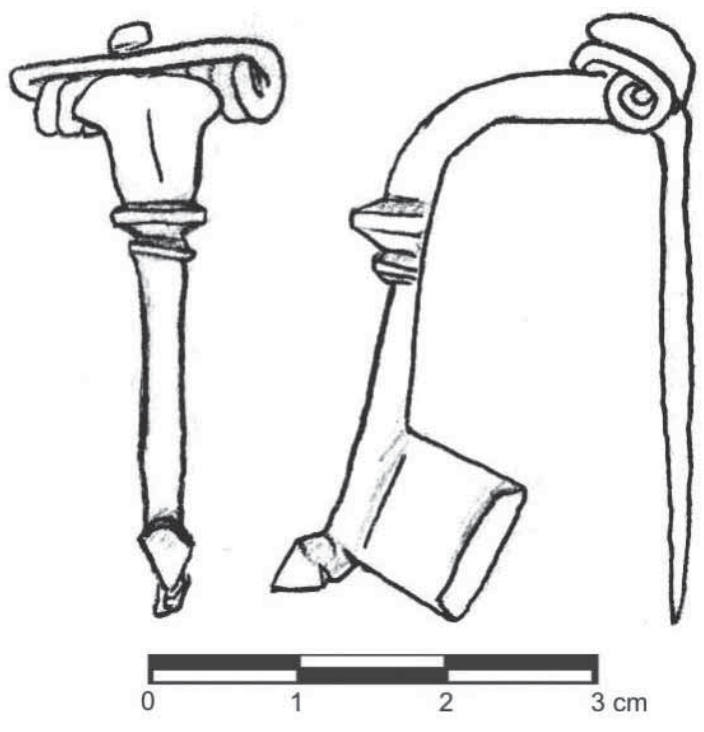

Fig. 27. Fibula, site Nad klepečkom C-136

sive linen, while the poor ones wore tunics made out of materials they could afford. Several sculptures and grave-steles were discovered in Viminacium, showing men in togas and tunics. Among the latest discoveries is a figurine made of quartzit, excavated near the amphitheatre (C-2489), whose head is missing, but according to folds, it can be seen that a person depicted is a man in a tunic and a long folded toga. (Fig. 25.) Some other sculptures discovered in Viminacium also show men in long tunics and richly folded togas, so one cannot follow the fashion of making togas shorter and
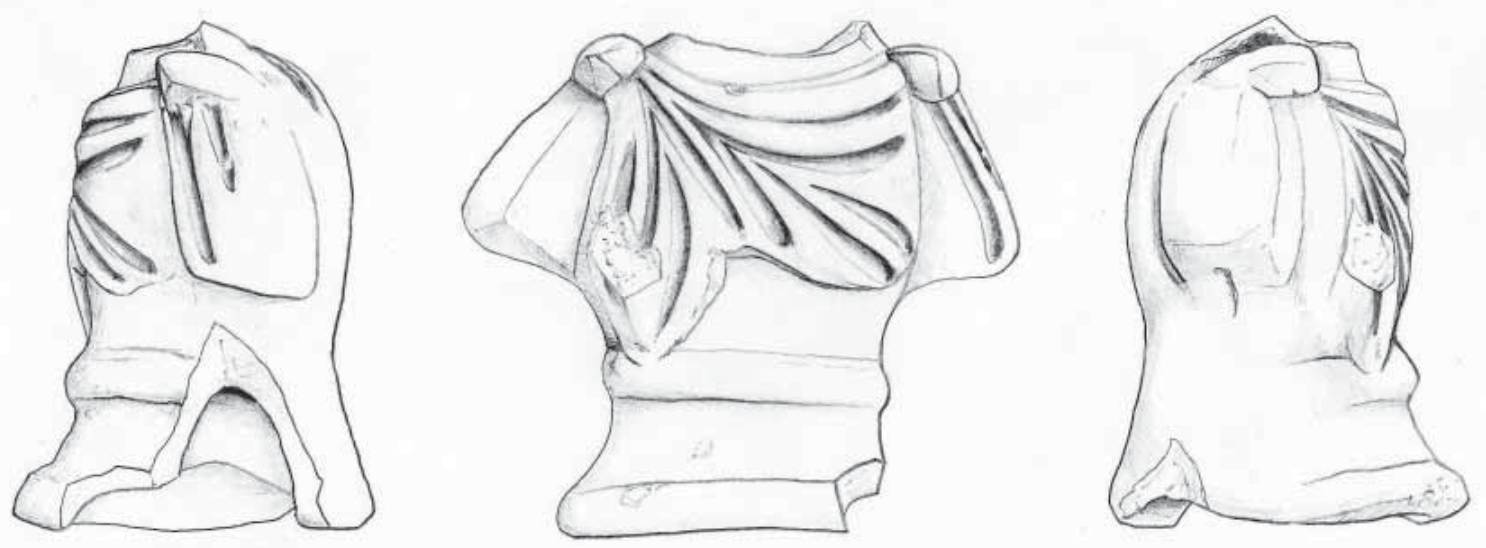

Fig. 26. Terracotta of a torso, site Nad klepečakom C-745 


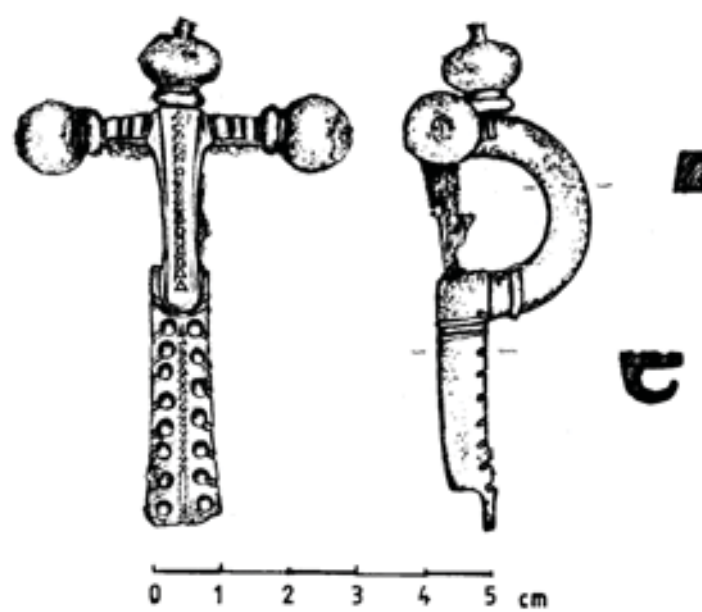

Fig. 28. Fibula, site Pirivoj C-560

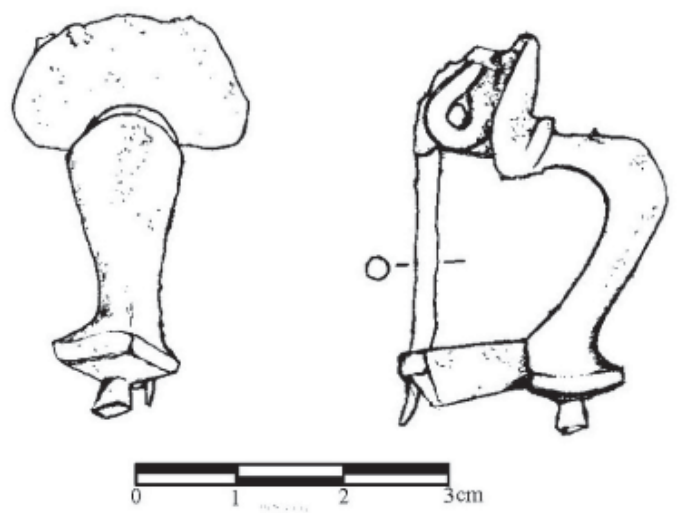

Fig. 29. Fibula, site Kod koraba C-208

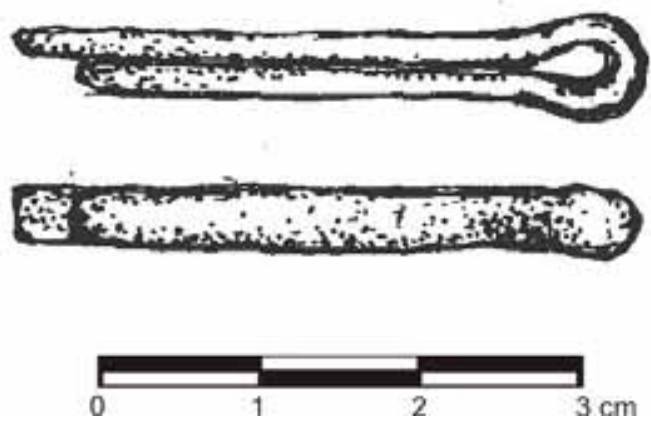

Fig. 31. Pincette, site Više grobalja C-1199 then abandoning this fashion completely. One of the reasons could be that there are only officials depicted in marble sculptures. The other, more plausible reason, is that only lately the area of the city was excavated and new finds of sculptures can be expected, offering new details. Changes in male fashon in Viminacium can be traced down on terracottas, but here again one comes accross cloaks, which were part of the military uniform and did not belog to everyday clothing. (Fig. 26.)

Clothes were fastened with different pins - fibulas, (Fig. 27-30), which are chronologically very sensitive. In excavated areas, they are found in a great number, divided into 36 types (Redžić 2007: 81-86). The three most numerous types include: 1 . Fibulas with hinges similar to Aucissa fibulas, 2. strongly profiled fibulas of Ponto-Danubian type and 3. knee-shaped fibulas with hinges. They were usually made of bronze, rarely covered with gold, but some examples were also made of silver. ${ }^{15}$ Some fibulas are considered to belong to female fashion exclusively, contrary to some other types, exclusively brought in connection with the military. Riots, which took place in the Balkan provincies during the middle of $3^{\text {rd }}$ century, brought poverty, decerease of imported raw materials and goods and finally led to abandoning certain types of fibulas.

After doing their hairs and dressing up,Viminacium women put their make up. Some of the images are shown on several frescos. On an already mentioned fresco from the tomb G-2624 a young woman, with outlined eye-brows and lashes is depicted (Korać 2007: 105). Viminacium's women and girls used all of the cosmetics also available today, only back at that time they were all of natural origin. White tan was acomplished by putting up chalk or lead powder. There was also a dip made of calves' hoofs, which was cooked on fire for forty days. Teeth were expected to look like two rows of pearls, which was

15 An especially interesting example was made of bone and carved in the shape of a pigeon. 

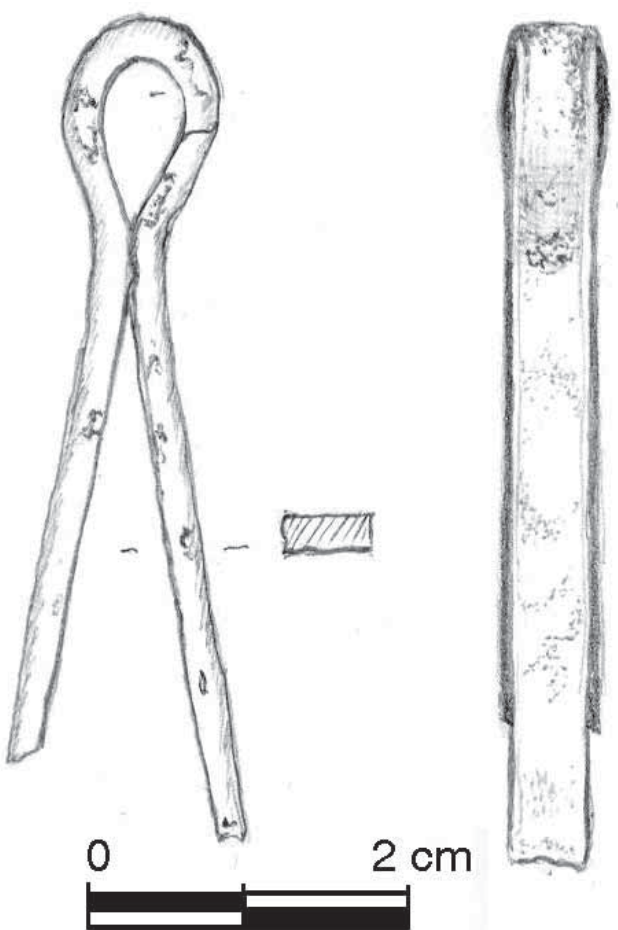

Fig. 31. Pincette, site Pirivoj C-375

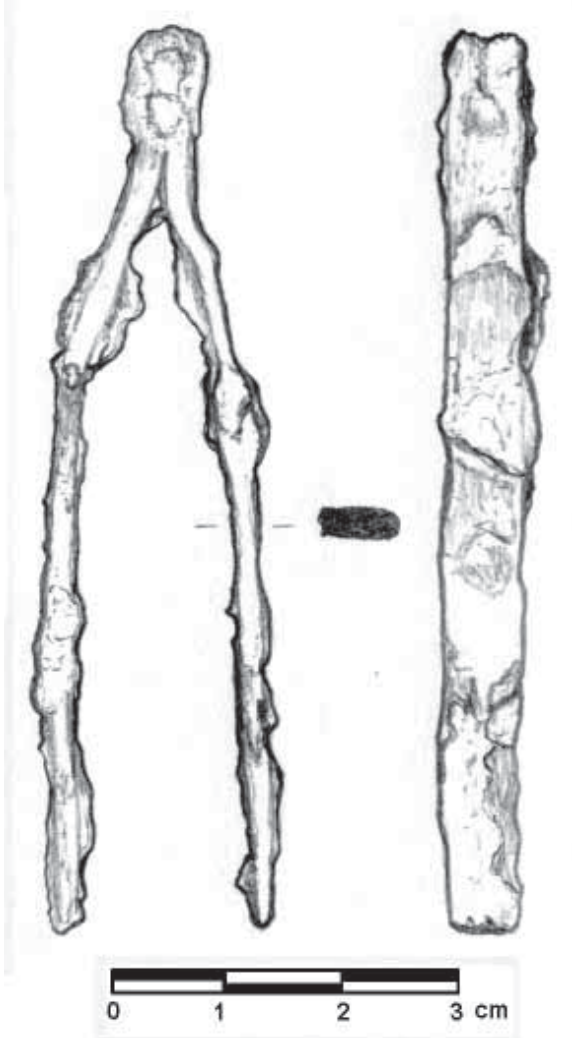

Fig. 31. Pincette, site Amfiteatar C-1054 achieved with rubbing with triturated cornelian cherries. A more unusual and horrifying variant was a triturated bone of ram's tail or powder made of deer's horn. White faces with red cheeks and black eye-brows and lashes were appreciated. Eye-brows were done with tweezers, ${ }^{16}$ (Fig. 31.) and then covered with black powder gained from soot and antimony powder. A "pen" was used for drawing lines around the eyes. Even then, men noticed that women did not sleep with their faces, which they have deposited in hudreds of jars. Such jars are often found at Viminacium. (Fig. 3234.) The reason for this is that until now, mostly the cemeteries were excavated. Since it was common to give personal belongings as grave-goods, many of the jars became grave-goods after their owner passed away. Cremes and perfumes were kept in vessels made of stone or lead, in order to stay fresh as long as possible. Such vessels were of long shape with a narrow openning and they were very expensive, because they were mostly imported. ${ }^{17}$ They were often replaced with cheaper vessels, made of clay or glass. They came in different shapes. Refreshment face masks, whitener and make up bases were kept in pyxides, mostly made of bone, (Fig. 35.) but also of many other materials. They consisted of three parts: a cylindrical body, bottom and lid. They were either simple or richly decorated with relief ornaments showing plants or figures. In long, narrow cylindrical vessels made of amber or glass found at site Pirivoj (C-383), blackener for the eyes was kept. It was put on eye-lashes with a thin stick made of wood or bone. In order to get all these cremes and powders out of the jars and boxes, spoons were needed, made out of different materials. Stone palettes were used for mixing (site $\mathrm{Nad}$ Klepečkom, C-74) and if something needed to be

16 Found also on sites Livade kod ćuprije, C-10; Velika kapija, C -187; Pećine, C- 435, 503; Više grobalja, C-400, 1303, 1314, 2503; Pirivoj, C-375; Amfiteatar, C-1054.

17 Sites Više grobalja, C-1470, 2048, 3138; Pećine, C-664, 1579, 1801, 2241, 2261, 2355, 2440; Nad Klepečkom C-70, 121, 299. 

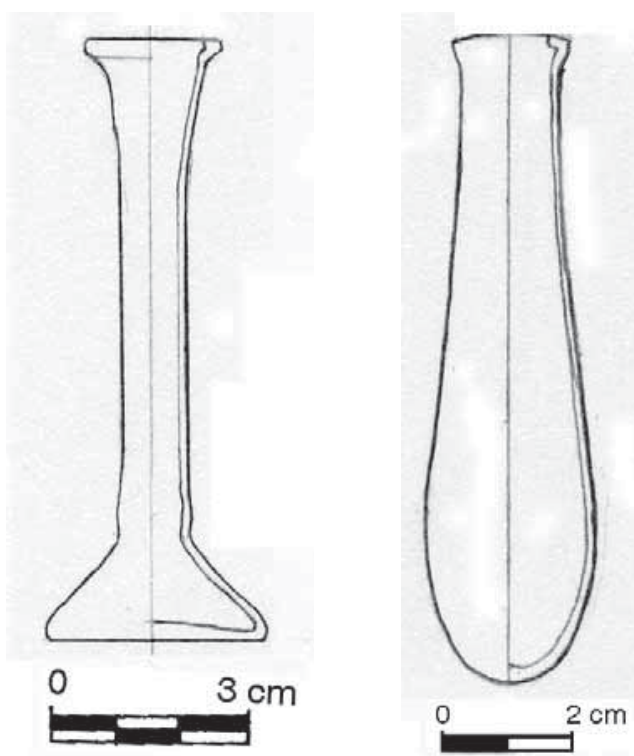

Fig. 32. Glass, site Pirivoj C-409 Fig. 33. Glass, site Pirivoj C-245

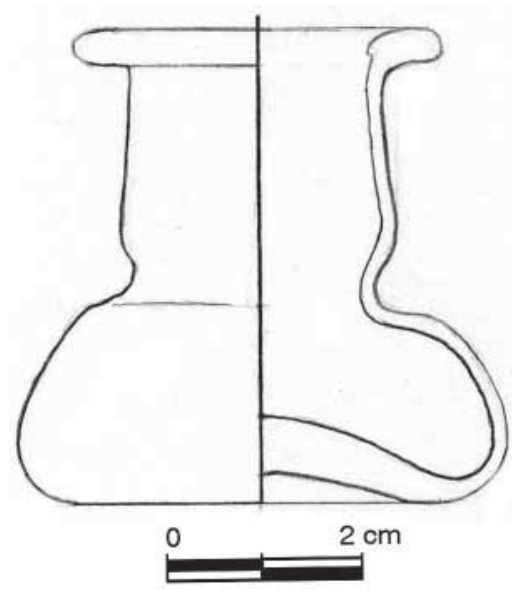

Fig. 34. Glass, site Pirivoj C-260

crashed, a marble mortar with a pestle (mortarium and pistillum) was used. A woman kept all of her make-up in a square wooden box (arcula) with a lid, which was either separated or connected to the box with hinges. During the excavations, hinges and applications, handles and locks are the most commonly discovered parts, while one can only guess what was kept inside of the boxes (site Nad Klepečkom, C-73, 124, 203, 299). (Fig. 36-38)

In order to see how they looked like, Romans used different mirrors (speculum). The technique of making mirrors was overtaken from

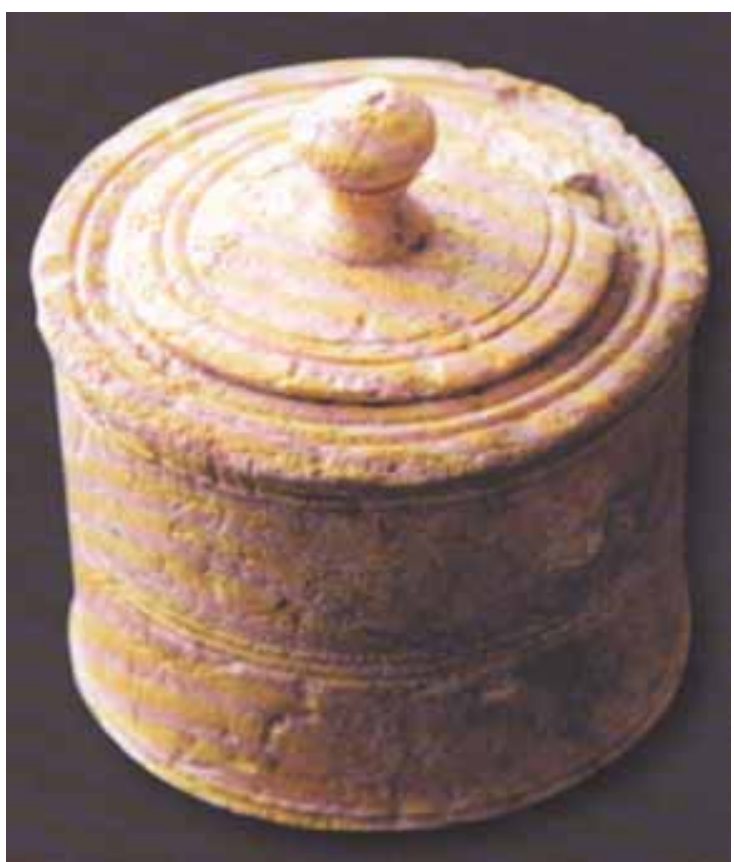

Fig. 35. Bone pixyda, Viminacium (СпасићЂурић 2002).

Greeks and Etrurians. There were hand-mirrors, or those hanging on walls and standing, mirrors with lids or mirrors on boxes. They were also of different sizes, from miniature to man-size. They were made of bronze with a high percentage of tin, zinc and lead. Discs were made on a turning lathe - whetstone, and then smoothened by polishing. In order to get a reflecting surface, mirrors were painted with a layer of amalgam (mixture of mercury and gold). Apart from simple, undecorated examples, there are those decorated with relief. Reliefs were done by punching bronze sheet on a matrix, and then they were covered with gold or silver. Such metal sheets were glued to the back of a bronze disc with a special white paste. One of the first mirror-makers was a Greek sculptor and toreut Passiteles ( $1^{\text {st }}$ century A.D.), who stamped his mirrors (Plinius 45: 9). The most famous centre in which bronze mirrors were made was in Brindisi in the South of Italy. Simple examples made of silver and bronze were sometimes only decorated with encarved concentric circles, punctuated along the edges (site Viminacium, Nad Klepečkom, C-528, Fig. 39.). The most luxurious 


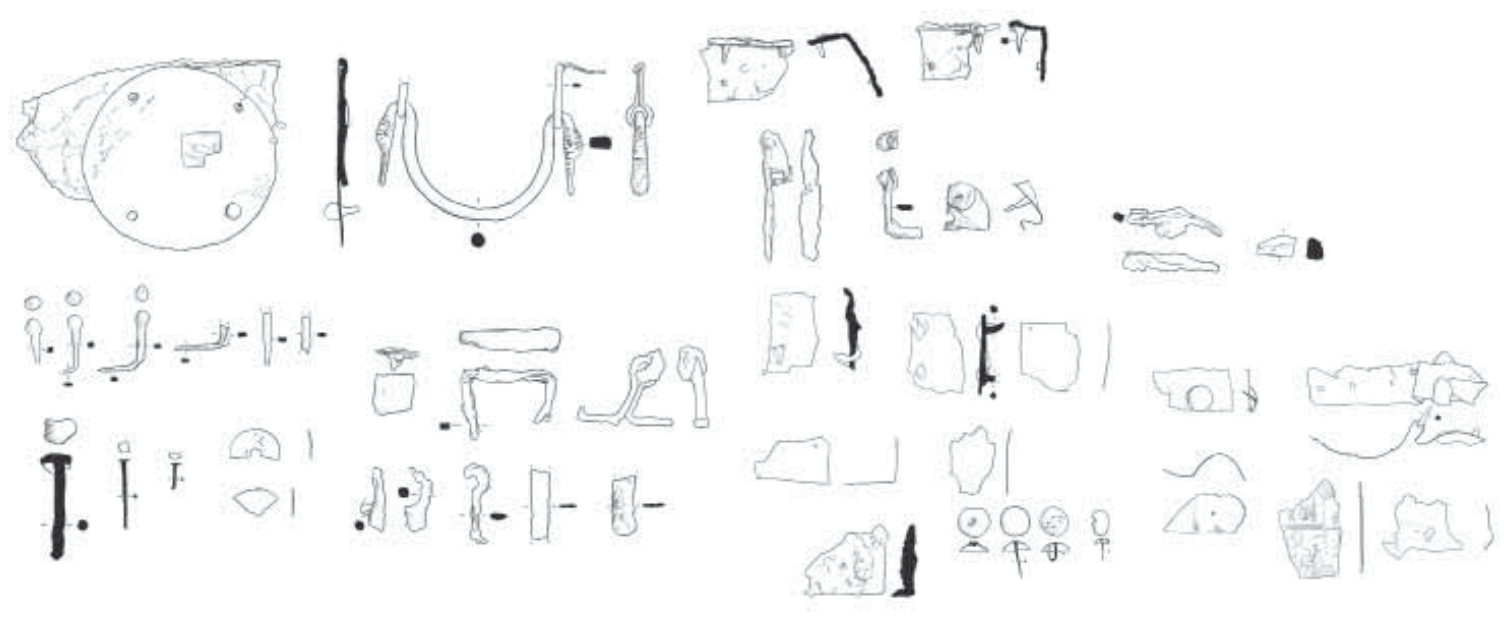

Fig. 36. Remains of a trunk, site Nad klepečkom C-203
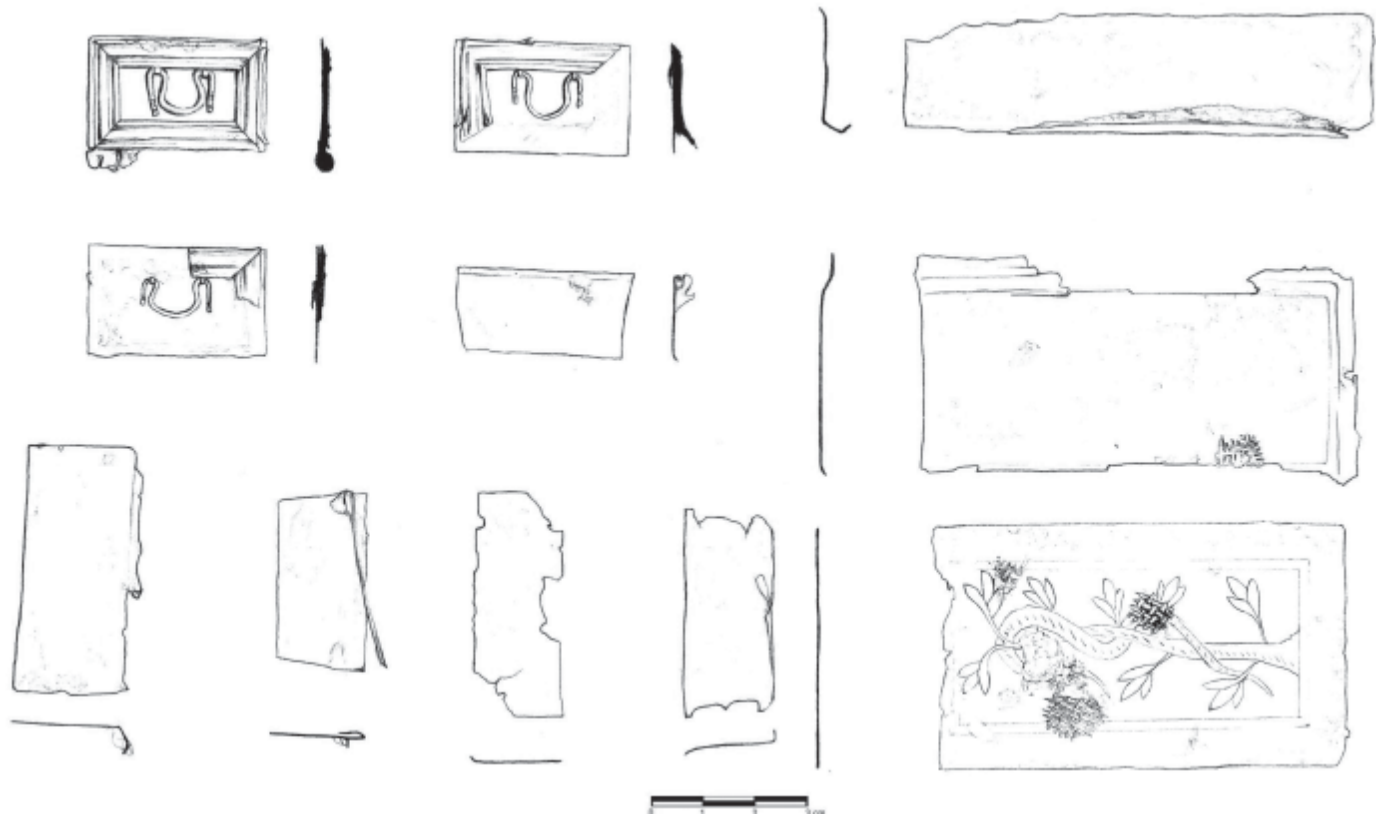

Fig. 37. Remains of a trunk, site Nad klepečkom C-73

mirrors from Viminacium were made of bronze with golden reliefs at the back side. They were found in graves at the site Pećine and Više grobalja (C-1769/R, G1-119, Fig. 40; C-6329, Fig. 41). Reliefs at the back side of the mirrors show mythological scenes like: Dionysus and Ariadne, Venus Victrix with three Graces or Proserpine. These examples belong to the time between the end of $2^{\text {nd }}$ to the middle of 3rd century (СпасићЂурић 2001: 159-178).
Apart from metal mirrors, there were also mirrors made of glass. They were first mentioned by an ancient author Alexander from Aphrodysios ( $3^{\text {rd }}$ century A.D.). The first mirror made of glass was discovered in Salzburg, dated according to Hadrain's coins. The Romans also used small convex glass mirrors. A plate of blown glass was glued (with a kind of resin) to a plate of tin, silver or gold, in order to get a reflecting surface. There was another, simplier method, which included a 

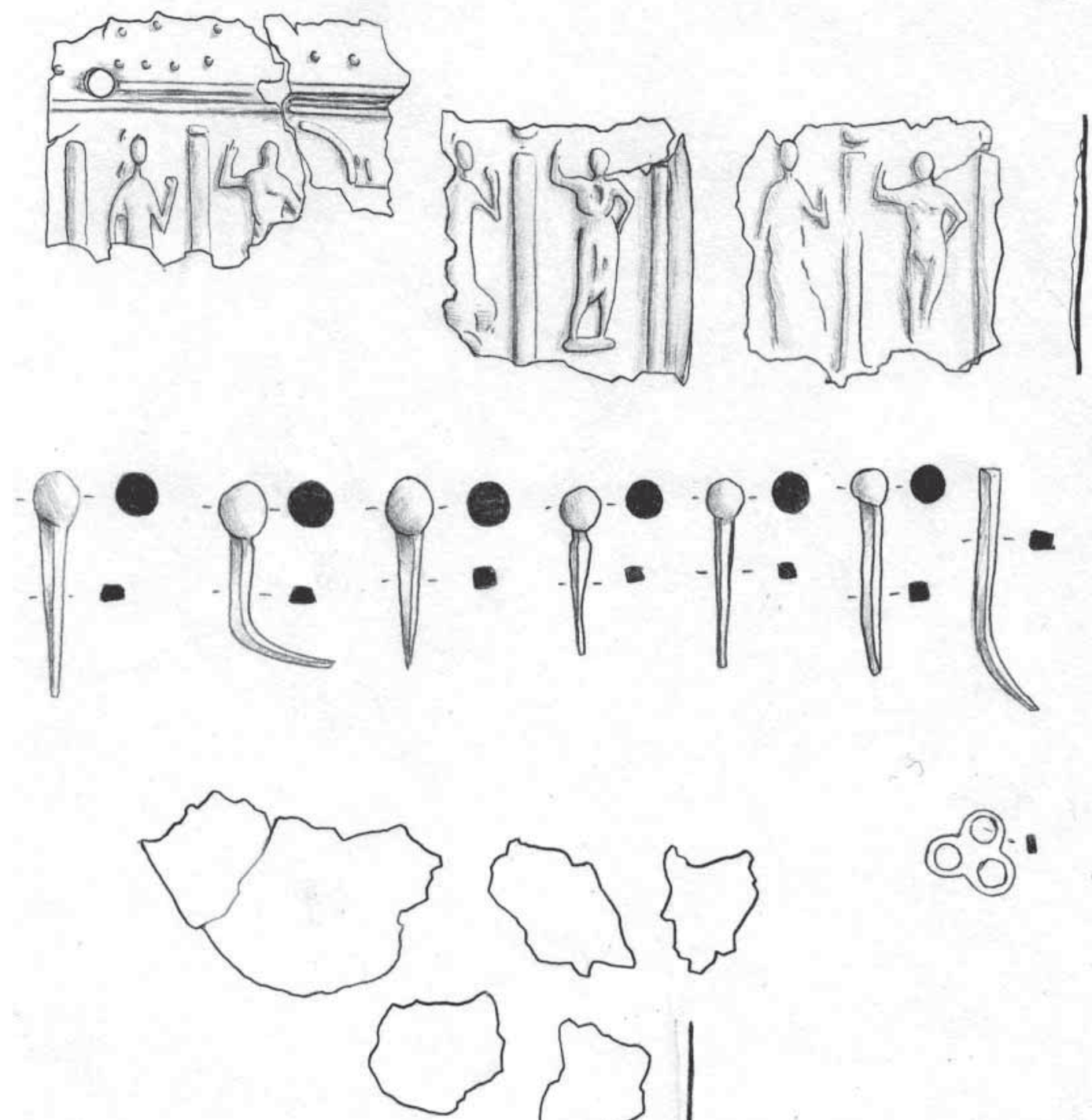

Fig. 38. Remains of a trunk, site Nad klepečkom C-123

bottle's side made of blown glass, out of which a circular or polygonal part was cut and a layer of melted lead was poured inside the concave part (Veličković 1959: 69-70; Спасић 1995-996: 40). In time, glass mirrors prevailed, because they offered a better reflection. Only since imperial times did the Romans use small lead mirrors (DAGR 1918: IV, 1429). Glass mirrors (with diameters from 1 to 3,5 cm) with lead frames (Спасић 19951996; Milovanović 2008: 45) represent numerous finds on Viminacium (sites Nad Klepečkom, C-17,
Fig. 42; Amfiteatar, C-1626, Fig. 43.). They are mostly round, with a handle, and rarely square. This type of mirrors, with rich geometric, floral or zoomorphic relief decoration on the frame, is of cultic purpose. Frames were casted, in single or double moulds. They are dated the period from the second half of $2^{\text {nd }}$ to the middle of $4^{\text {th }}$ century. They are mostly found accidentall, and only a small number was discovered in graves. Mirrors as grave goods can be brought in connection with the cult of Venus Funeraria. Venus was the only 


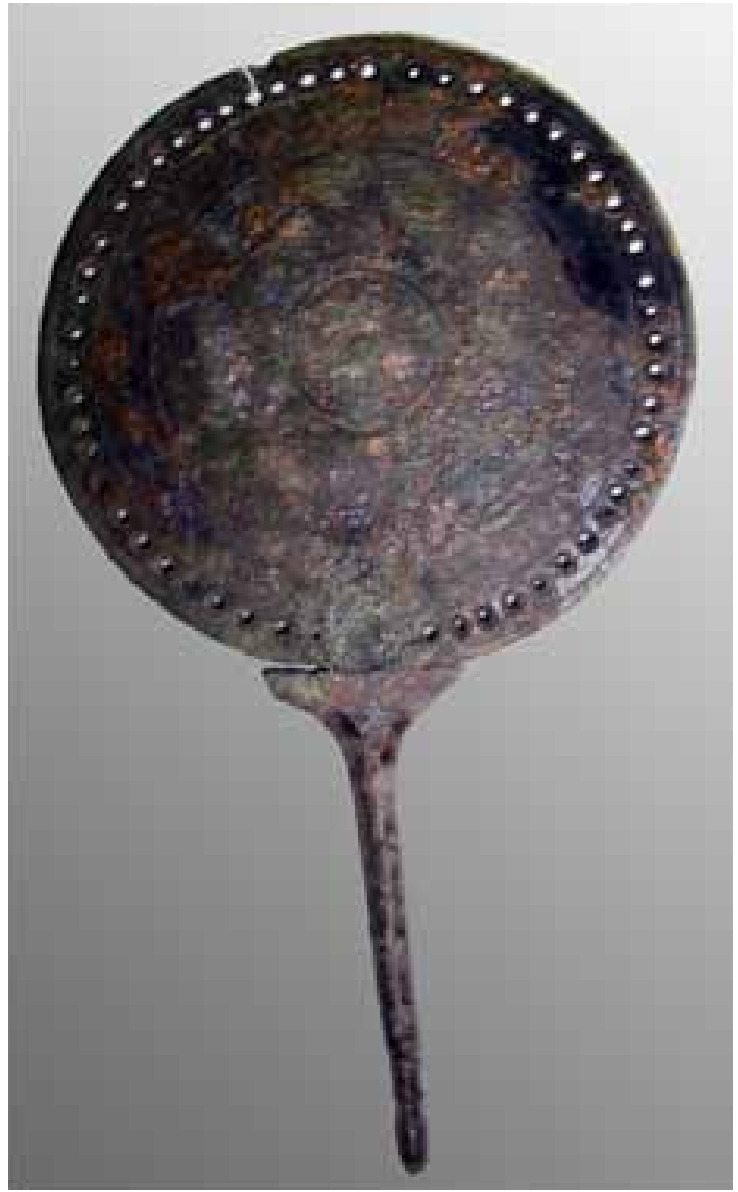

Fig. 39. The bronze mirror.

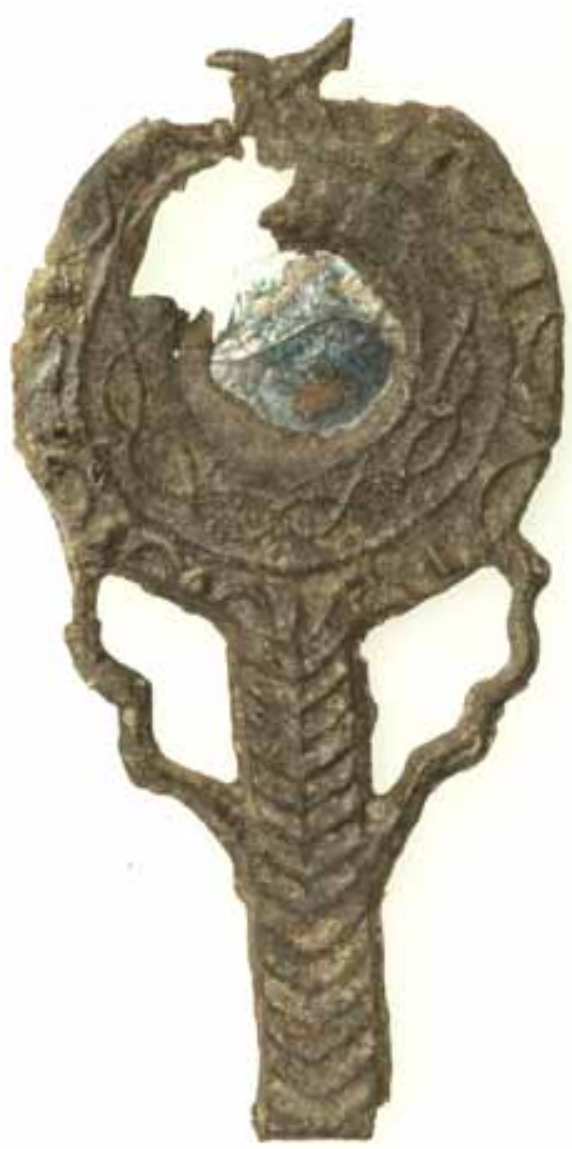

Fig. 43. The mirror with lead frame.

paste or often by combinig them. It was important to be showy. Such a style was popular in the middle of 2nd century and especially in 3rd century, when it was also known as "the polychrome style" (uniones) (Поповић 1996: 14, 57). Apart from metal, jewelry was also made of precious stones, bone, glass paste or jet (natural resin).

One of the favourite kinds of jewelry were necklaces made of double or multiple twisted chains, like fox-tails. They appear throughout the whole Antiquity, often worn with pendants (crescents, coin-pendants 


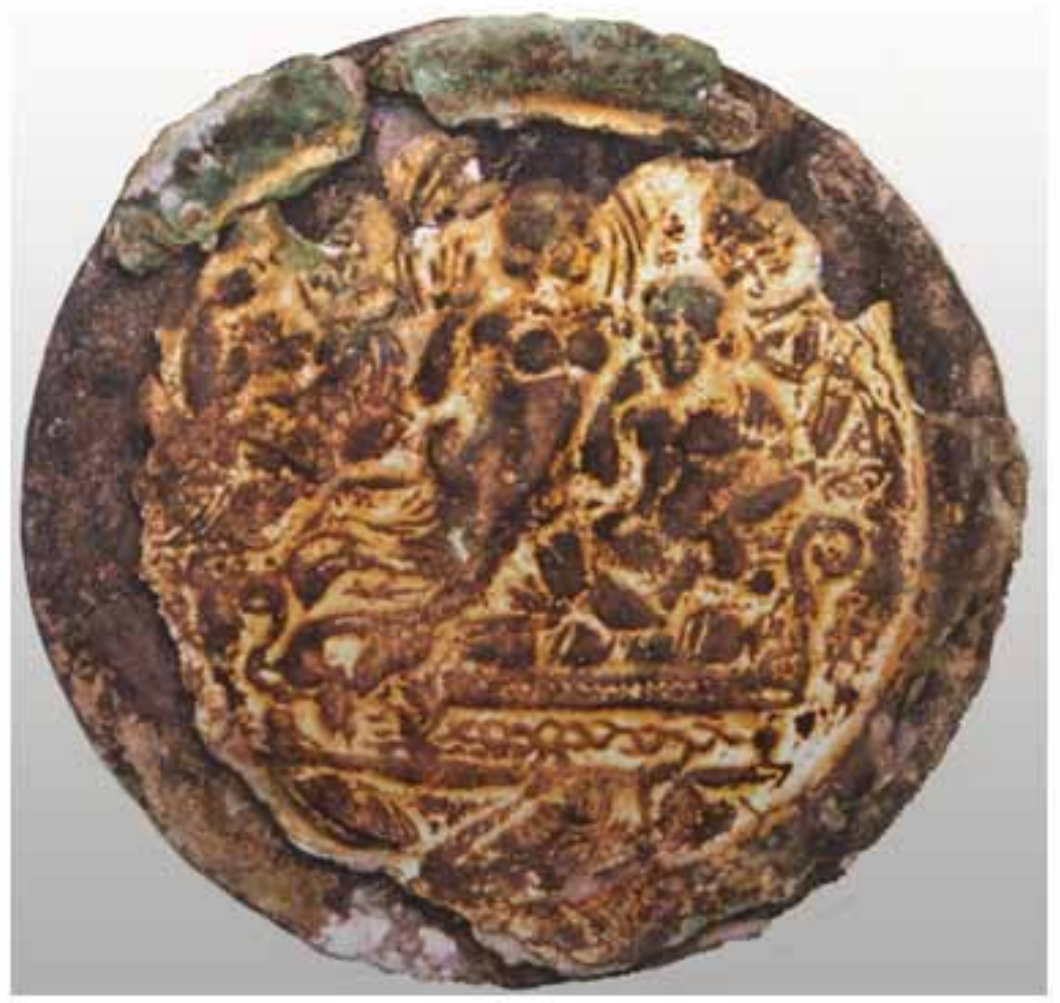

Fig. 40. The bronze mirror with golden reliefs of Dionis at the back side.

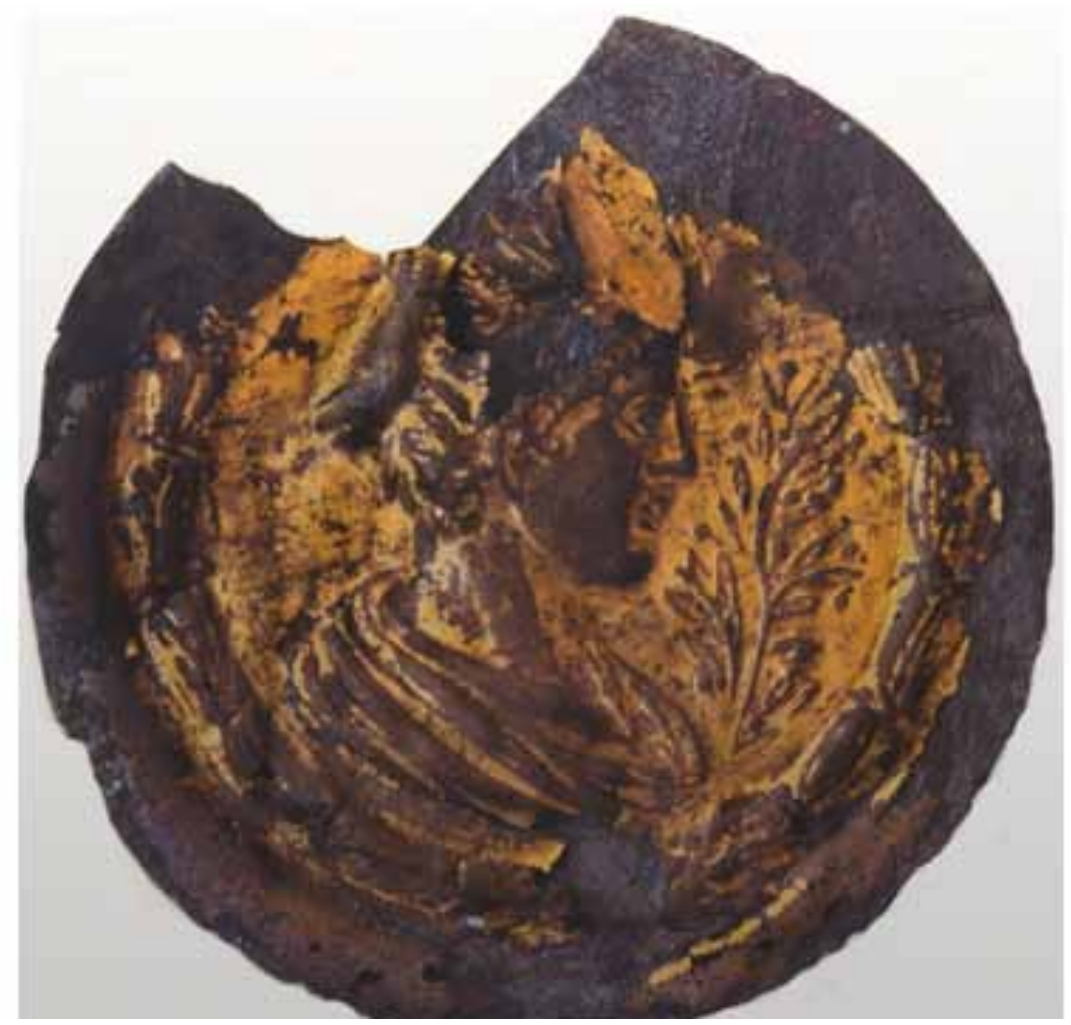

Fig. 41. The bronze mirror with golden reliefs of Proserpine at the back side. 
or bulls). Combined articulated chains made of parts in the shape of an " 8 " and connected with loop-shaped wires and pearls were named hormoi, because they were made out of pearls of different materials and colours (glass paste, pearls, precious stones, golden tin, bone). Some examples have heart-shaped pendants with a pearl in the middle (site Pirivoj, C-349, G-134, Fig. 44). Luxurious and heavy necklaces made out of paste pearls, jet or gold, with massive and heavy pendants medallions, gemmes or cameos, were produced from the second decade of 3rd century and they are typical for late Antiquity (Поповић 1996: 3738, type IV). The Viminacium examples chronologically correspond to this period (site Pirivoj, C-846, Fig. 45). Pendants were mostly worn on necklaces, but sometimes also on bracelets. They were mostly made of metal combined with precious stones, although there are some examples made of bone and glass paste.

A typically Etrurian pendant, also worn by the Romans, was a bull, actually two metal calottes put together, carried on a ribbon. In time, bulls became symbols of Romans born as free cit- izens. During the early imperial period, they were worn by children and young girls. In Viminacium, they were found in graves of newborns, one-yearolds and of a fifteen-year-old girl (Pirivoj, C-295, Fig. 47). Under hellenistic influences, crescentshaped pendants reach their peak during Roman times. Metal crescents with a hooks were worn as amulettes and were often given as birthday gifts. From the first half of $1^{\text {st }}$ to $4^{\text {th }}$ century, they were worn on chains and torqueses. Examples from Viminacium are numerous (sites Više grobalja; C-4112, G-596, Fig. 48). In the middle of 2nd century, pendant - medallions with gemmes and cameos were worn, also dominant during 3rd century. They were worn on chains and necklaces, but they could also build parts of earrings. Female profiles with precisely depicted hair-styles or Medusa's head were common images depicted on cameos (site Pirivoj, C-846, Fig. 46). A great number of examples found at Viminacium indicates that there was a workshop in which gemmes and cameos were produced (Поповић 1989: 11).

Apart from necklaces, earrings (inuares) were also worn by Roman women. After hellenis-

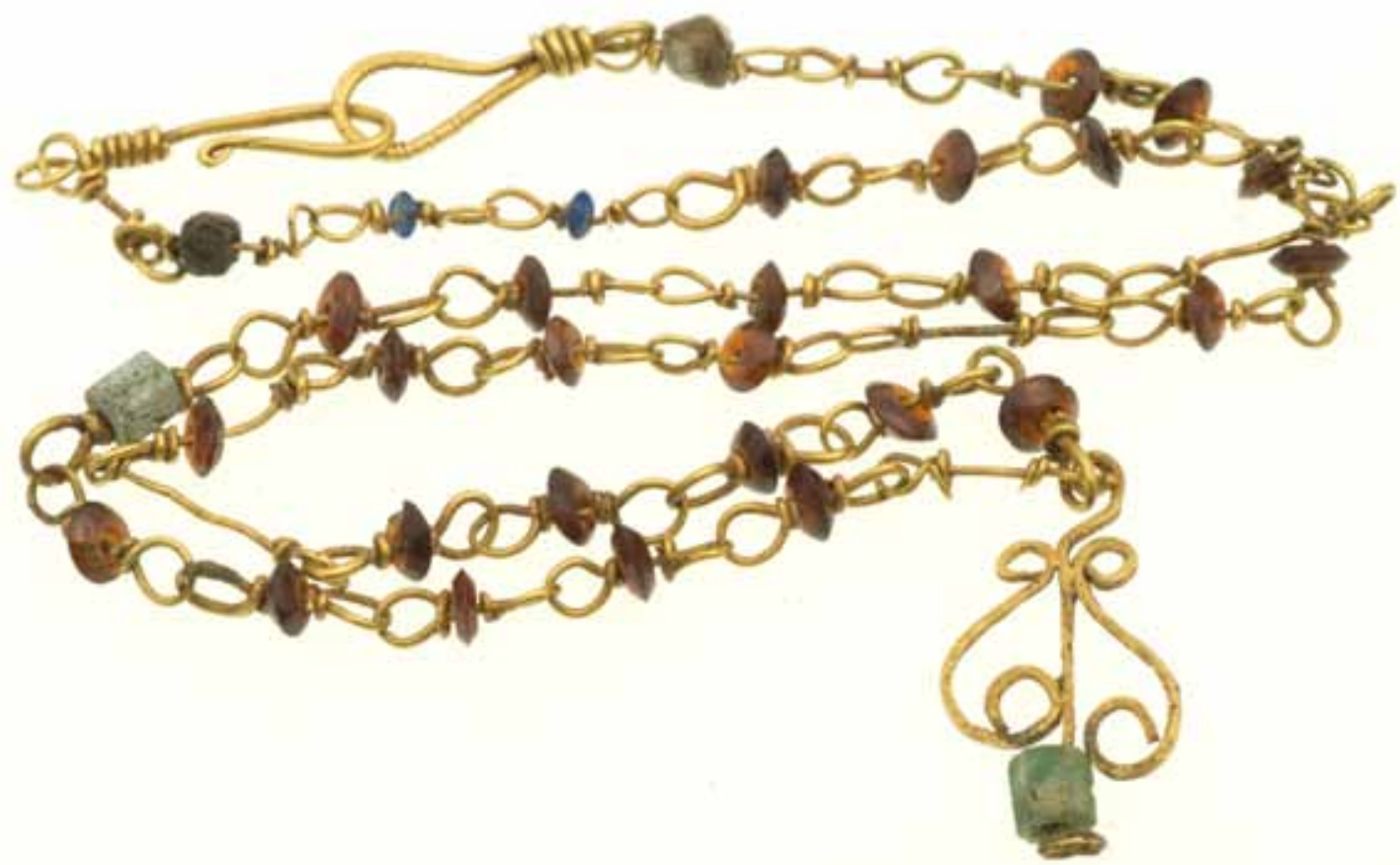

Fig. 44. The necklace with a heart-shaped pendants with a pearl in the middle. 


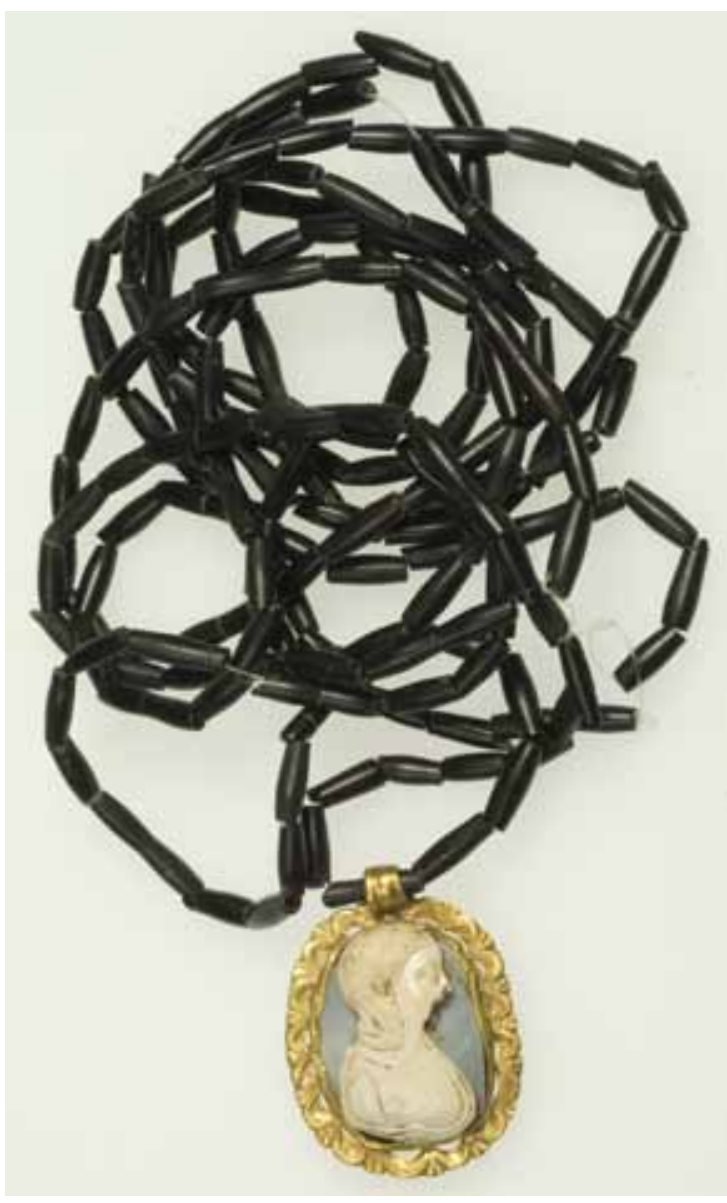

Fig. 45.The necklace made out of paste pearls with massive pendant-medallion with cameo.

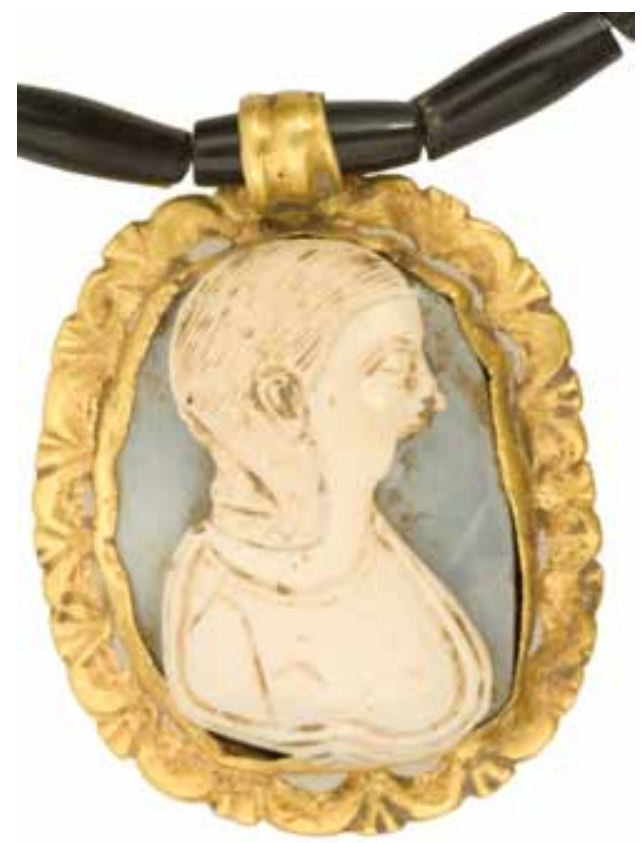

Fig. 46. The pendant - medallions with cameo. tic traditions, the Romans developed this type of jewelry into a new style, developing in such a way a greater typological variety. Viminacium earrings can be divided into thirteen types, with numerous variants and sub-variants (Milovanović 2003: 131-143). The basic division is achieved according to the principle of closing and so there are earrings made as simple rings (with opened or closed endings) and those with an "S"-shaped hook for fixing. Pendants can be added to both of the types (Milovanović 2007: 11). Luxurious Viminacium examples were made of gold with precious stones in gouging, perforating and bending techniques (sites Pirivoj, C-913, Fig. 49, C-843, G-290, Fig. 50, C-487, Fig. 51). Such examples are dated into $2^{\text {nd }}$ and $3^{\text {rd }}$ century, while the ring-shaped earrings were less luxurious and they were worn until the end of Antiquity (sites Pirivoj, C-164, Fig. 52).

Armrings (armillae) were usually worn around wrists or, in some cases, around upper arms or ankles. Apart from their decorative function, in the military they also played a role of military insignia, together with torques and phalerae. Massive armrings were given to soldiers as dona militaria (Petrović 1991: 67). They were made out of metal, glas paste, jet and bone. They are divided into two main groups: armrings with closed and with opened endings. The earliest examples known from this region were made of silver and bronze, with overlapping and twisted endings. Chronologically, they belong to the second half of $1^{\text {st }}$ century (Viminacium site Pećine, C-342, Fig. 53). One of the examples from Viminacium has a bull as pendant (site Pećine, C-2337, G1-173). Armrings closed with a hook and a loop were variously decorated. They were made out of smooth or twisted wire (site Pirivoj, C-314, Fig. 54) and dated into $3^{\text {rd }}$ and $4^{\text {th }}$ century. The most numerous are the armrings with opened endings, which were decorated with carvings, broadened or narrowed (site Pirivoj, C-343, G-135, Fig. 55) or ending in the shape of snake-heads. Examples with snake's head on one and tail on the other ending are some- 


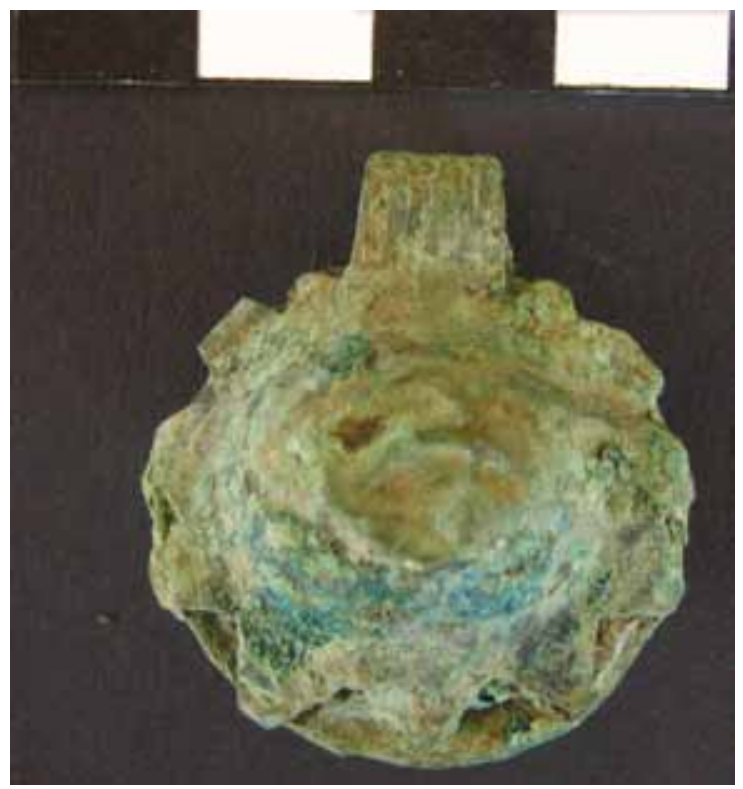

Fig. 47. The bronze bull.

what older (they date from $2^{\text {nd }}$ to the first half of $4^{\text {th }}$ century), while only later, the type with snake's heads on both endings prevail. It is actually a Greek-hellenistic form, which was broady accepted by the Romans (Поповић 1996: 50-51). Finds of this kind are rather numerous in Viminacium (site Pirivoj, C-683, Fig. 56). Apart from smooth bracelets, there were also massive examples made out of twisted wire (sites Pirivoj, C-685, Fig. 57). Two bracelets with lion's heads on endings were also discovered at Viminacium. One was made out of twisted bronze wire with lion's heads formed afterwards (site Pećine, C-2168, G-633), while the other was made of thick bronze wire around which a thinner bronze wire was twisted (site Pećine, C-2168, G- 633). They are dated at the end of $3^{\text {rd }}$ and the beginning of $4^{\text {th }}$ century (Радуловић 2006: 361-362, Type VI, Fig. 2e, ж).

Rings consisting of pearls are typical examples of polychrome style, worn as necklaces and earrings in $2^{\text {nd }}$ and $3^{\text {rd }}$ century. Pearls were made of glass paste or jet, smooth or carved. They are usually found fragmented and pearls are scattered around the hands of the deceased, indicating that they once were armrings. Armrings made of bone belong to rare finds. Several fragmented or

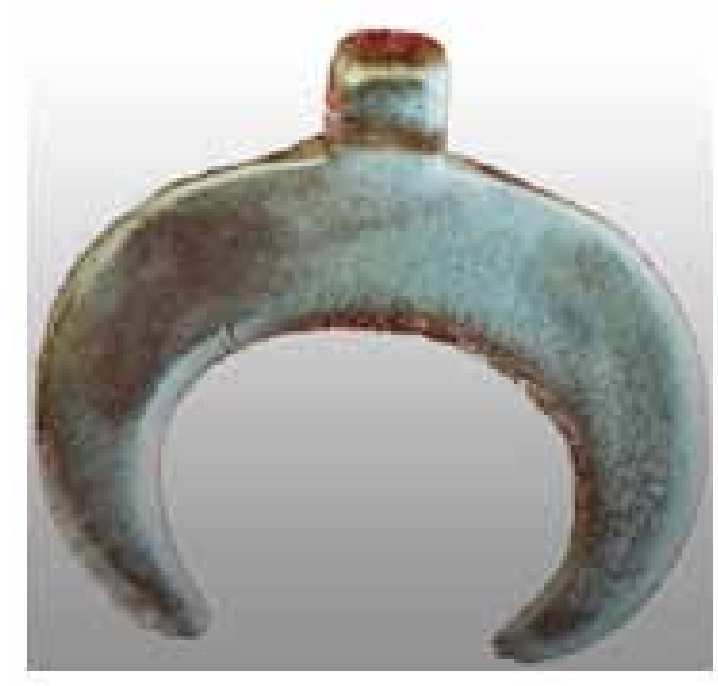

Fig. 48. The bronze crescents with a hooks.

whole examples were found at Viminacium. They are usually smooth or decorated with horzontal canelures. Bone armrings with overlapping endings and closed with bronze buttons belong to common finds (Pirivoj C-433, Fig. 58). Closed armrings can be ring-shaped, made of thick or thin wire. Simple examples were not decorated, while most of them have carved or perforated decoration (sites Pirivoj, C-754, Fig. 59). Chronologically, they mostly belong to $4^{\text {th }}$ cenutry.

First fingerrings were used as stamps. In Greek, Hellenistic and Roman times, fingerrings became a part of fashion and were produced in different shapes. The Romans accepted the tradition of wearing fingerrings from the Etrurians (Поповић 1992: 9). During the time of the Republic, iron fingerrings were worn, while golden examples represented dignity and were worn only by the wealthy and their heirs. In time, wearing golden fingerrings was also allowed for the first eight centurions. At the beginning of the Empire, golden fingerrings were still a feature of patritii only, but with an imperial permission, such a privilege was sometimes also given to some of the lower ranking persons. Only did Hadrian allow the usage of golden finderrings to broader masses, with the exception of 
slaves. Septimius Severus allowed his soldiers to wear golden fingerrings (Поповић 1992: 7).

In $1^{\text {st }}$ century B.C., some of the Romans posessed collections of fingerrings and precious stones (gemmes and cameos). The first collection of this kind was established by Sulla's son-in-law, Marcus Aemilius Scarus. Later on, Pompeius and Iulius Caesar also established such collections. The first Roman emperos, Octavian Augustus, first wore a fingerring with a gemme with an engraved sphinx and later on a gemme with the image of Alexander the Great. Massive and heavy fingerrings were appreciated very much (Поповић 1992: 7). ${ }^{18}$

Shapes of fingerrings depended on their purpose. If they were meant for stamping, they had to be massive, in order to endure the pressure, but if it was just a decorative ring, it was finer and less heavy. Fingerrings of the same shape were made of different kinds of metal (gold, silver, bronze and iron) and decorated with encarving different motives or inlaying paste or precious stones (Поповић 1992: 9). Fingerrings often bore heads with inlayed gemmes or, less commonly, cameos, such examples were found at Viminacium (sites Pirivoj, C-751, G -212, Fig. 60). Simplier examples had inlayed glass apste instead of precious stones (site Pirivoj, C-848, Fig. 61). None of the forms were exclusively made of one kind of metal. Apart from stamp-fingerrings, there were also engagement rings (anulus pronubus), which did not differ much from other kinds of rings (site Više grobalja, C-2945, G1-345, Fig. 62). Examples of fingerrings made of glass paste are known, imitating metal fingerrings (site Pećine, C-201, Fig. 63 ), but there are also examples made of precious stones, amber and bone. Here ends the journey through the fashion of Viminacium, with hope that future excavations will offer even prettier finds. Such finds will show that this city was not just the place of many workshops, but also a city whose inhabitants had sense for fashion and beauty.

18 Speaking about certain Zoil, Martial mentions that he wore such massive rings, as if they were meant to be worn on toes.

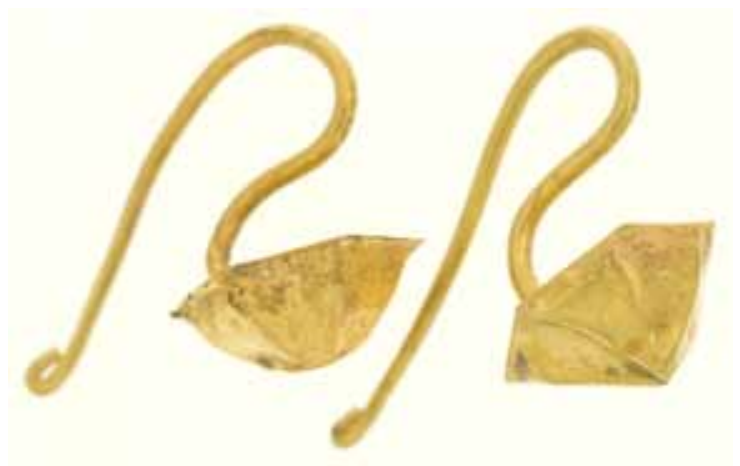

Fig. 49. The gold earrings with a "S"-shaped hook for fixing.

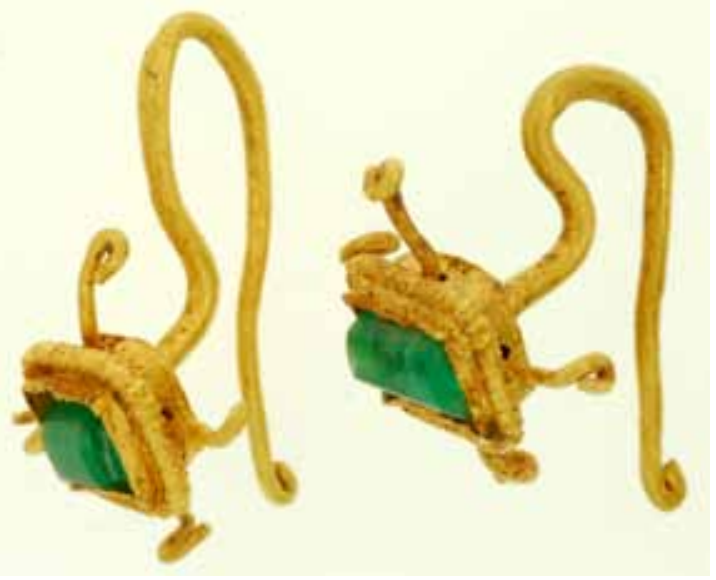

Fig. 50. The gold earrings with a "S"-shaped hook for fixing.

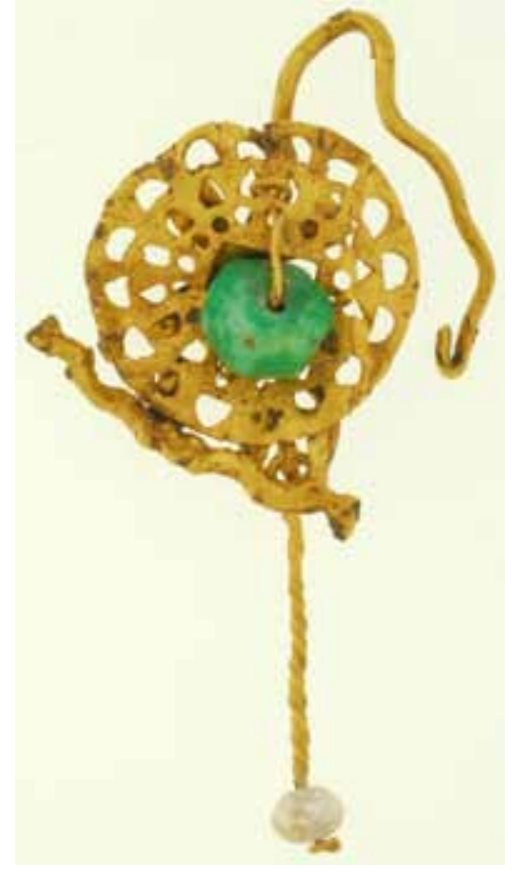

Fig. 51. The gold earring with a "S"-shaped hook for fixing 


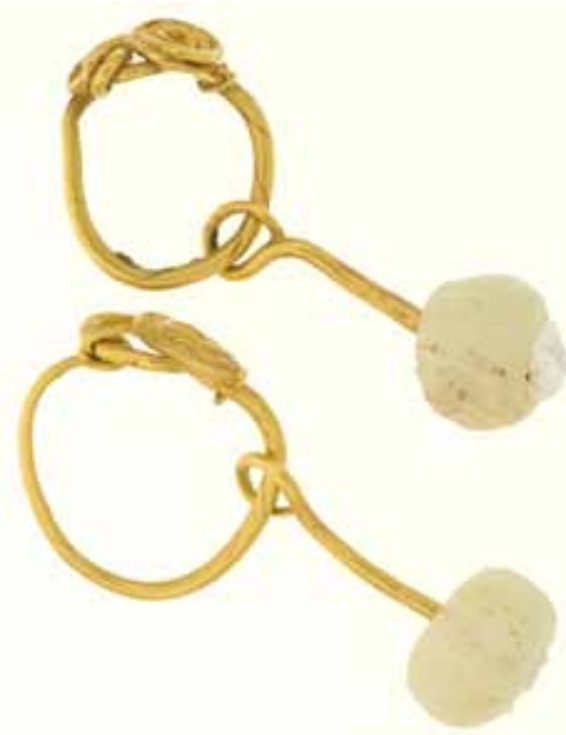

Fig. 52. The gold earrings

with a ring-shaped hook for fixing.

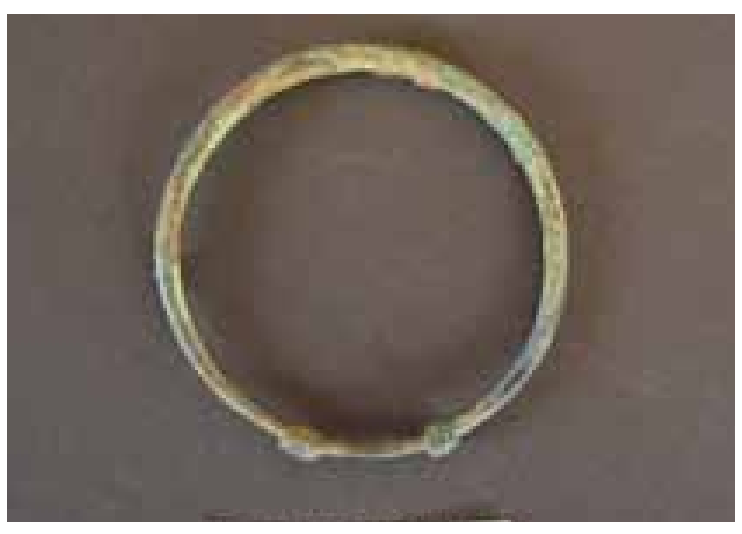

Fig. 53. The bronze armring with overlapping and twisted endings.

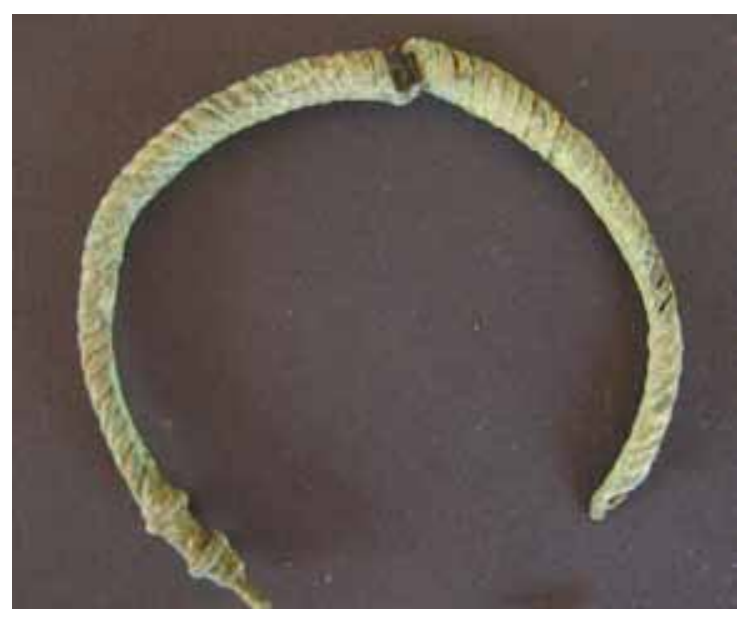

Fig. 54. The bronze armring closed with a hook and a loop.

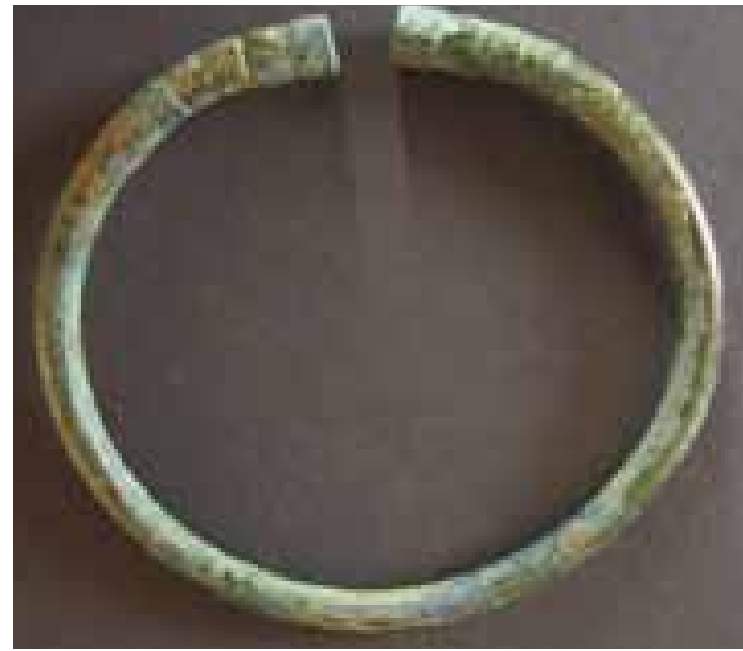

Fig. 55. The bronze armring with opened endings.

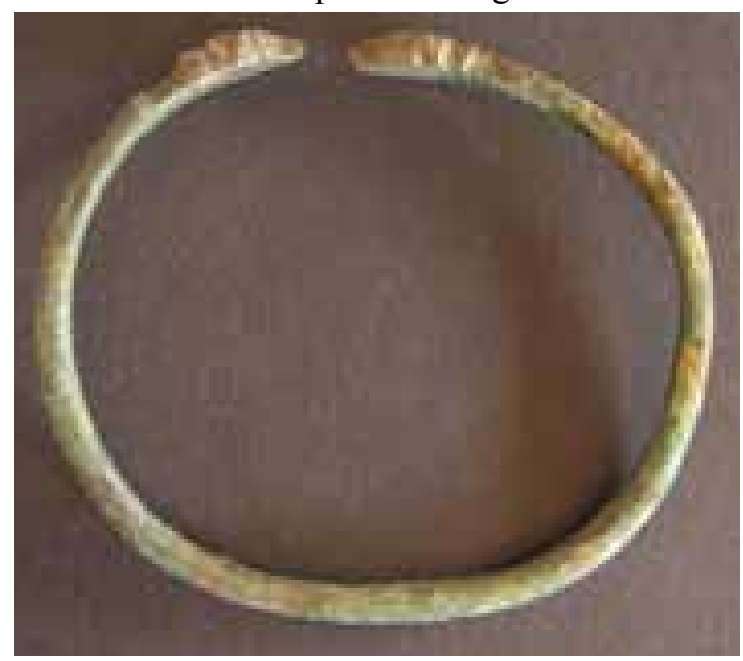

Fig. 56. The armring with ending in the shape of snake-heads.

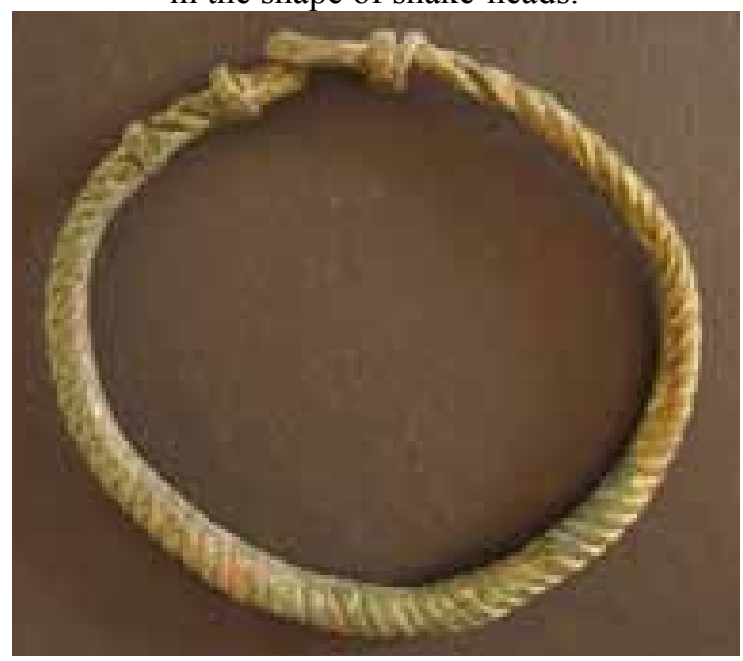

Fig. 57. The bronze armring of twisted wire. 


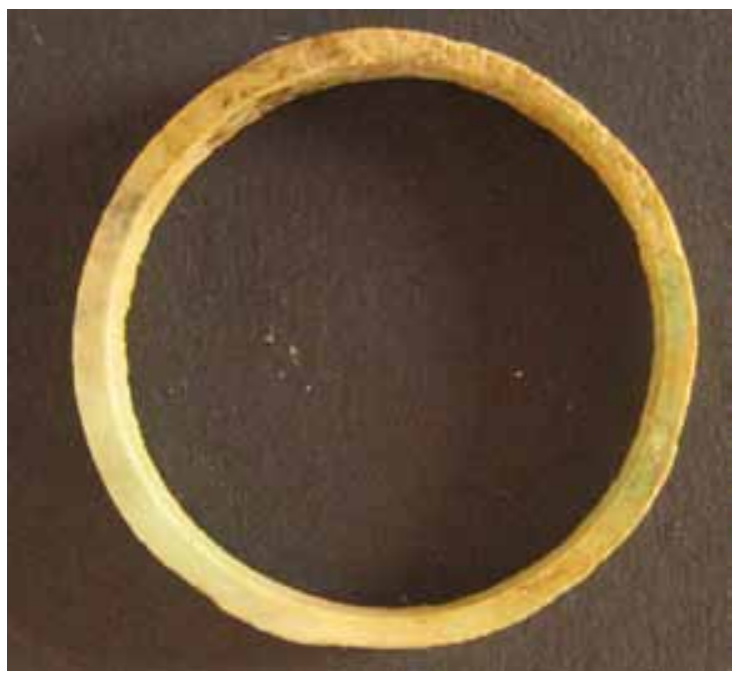

Fig. 58. The bone armring.

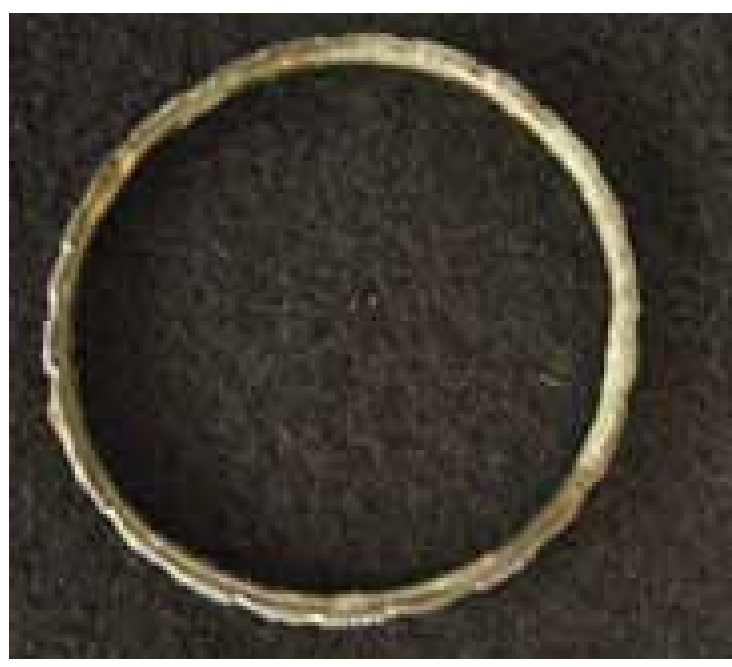

Fig. 59. The closed armring with carved decoration.

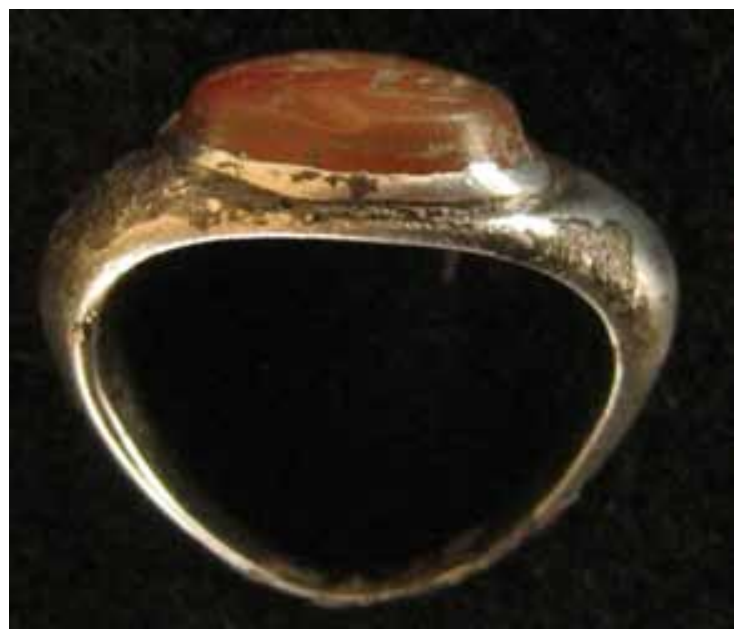

Fig. 60. The silver fingerring with gemme.

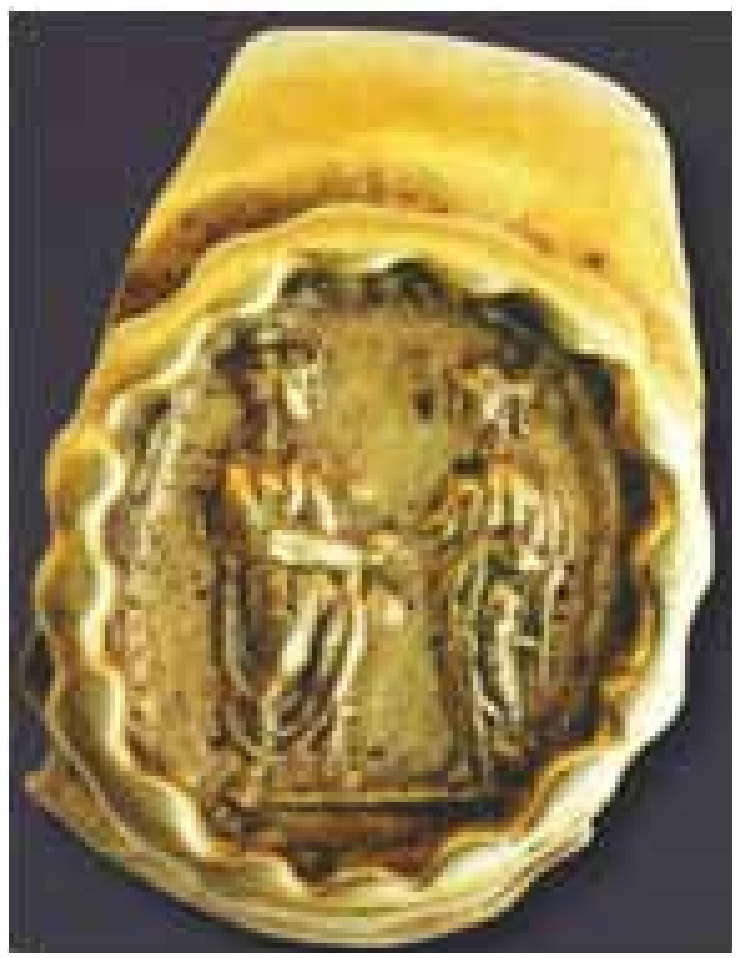

Fig. 62. The gold stamp-fingerring.

Fig. 61. The gold fingerring with rubin. 


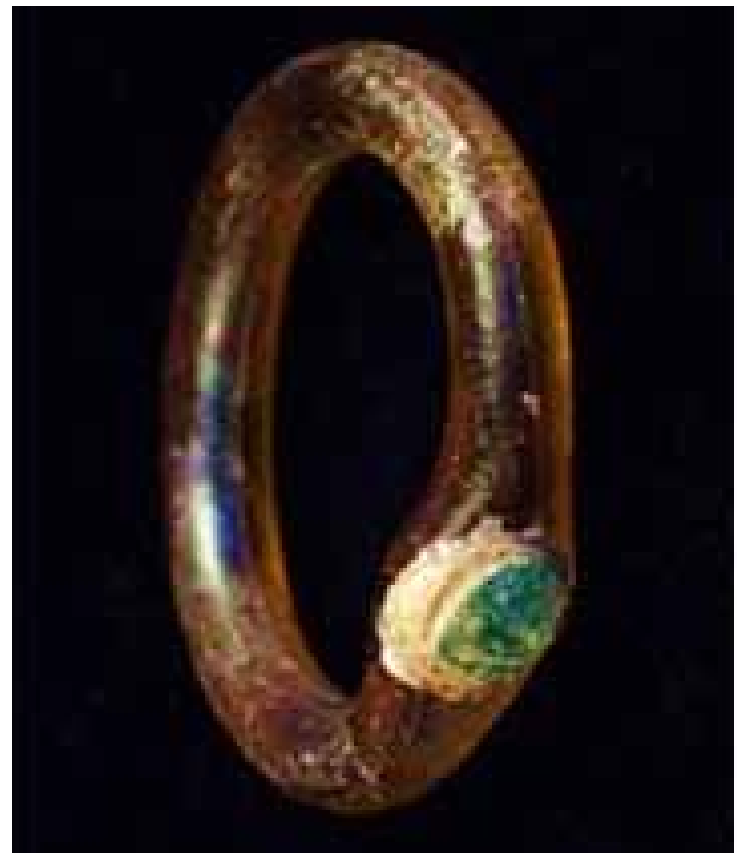

Fig. 63. The glass fingerring.

\section{LITERATURE}

\section{Beatson, P., 2004}

Roman costume quide (http://members.ozemail. com.au/chrisandpeter/radical_romans/female/female.htm)

\section{Buzov, M., 2008}

Plautilla, sudbina jedne princeze. Archaeologia Adriatica II, No. 2, Zadar: Sveučilište u Zadru, 473-488.

\section{Croom, A. T., 2000}

Roman clothing and fashion, Gloucestershire: Tempus

\section{Daremberg, A. and Saglio, M. E., 1918}

Dictionaire des Antiquités Grecques et Romaines, Tome IV, 1, Paris

Голубовић, С., 2000

Обућа из триконхалне гробнице из Виминацијума, Viminacium 11, Пожаревац: Народни музеј Пожаревац
Jevtović, J., 1987

Antički portret u Jugoslaviji, Beograd: Narodni muzej Beograd

\section{Јовановић, А., 2000}

Култ Venus Funerariae у Горњој Мезији, Зборник Нишког музеја 9, Ниш: Народни музеј Ниш, 9-15.

\section{Korać, M., 2007}

Slikarstvo Viminacijuma, Beograd: Centar za nove tehnologije

\section{Korać, M. and Golubović, S., 2009}

Viminacium - Više grobalja 2, Beograd: Arheološki institut.

\section{Lalović, A., 2007}

Moda i ulepšavanje u antičkom Rimu, Anarheologija nr. 3

(http://www.field-archaeology.com/clanci/ lalovic2/index.php).

\section{Milovanović, B., 2003}

Earrings, symbols of femininity of Viminacium's women, ANO $\triangle$ OS - Studies of the Ancient World 3, Trnava, 2003, 131-143.

\section{Milovanović, B., 2007}

Nalazi naušnica u rimskim provincijama na teritoriji Srbije, Beograd: Centar za nove tehnologije

\section{Milovanović, B., 2008}

Rimsko olovo u Srbiji - eksploatacija, proizvodnja i upotreba, Doktorska disertacija, Filozofski fakultet, Univerzitet u Beogradu

\section{Milovanović, B. and Mrđić, N., 2008}

The She-Wolf Motif with Romulus and Remus on a Tomb Stela of an Augustal from Viminacium. International Congress of classical archaeology meetings between cultures in the Ancient Mediterranean, Volume Speciale, Roma. 
Петроније, А., 2007

Сатирикон, Београд: Српска књижевна задруга

Petrović, П., 1991

Dona Militaria, Старинар (н.c.) XLII, Београд:

Археолошки институт Београд

Bostock, J. and Riley, H. T., 1855

The Natural History, Pliny the Elder, London: Taylor and Francis

Поповић, И., 1989

Римске камеје у Народном музеју у Београду, Београд: Народни музеј Београд

Поповић, И., 1992

Римски накит у Народном музеју у Београду, Прстење I, Београд: Народни музеј Београд

Поповић, И., 1996

Римски накит у Народном музеју у Београду,

Златан накит II, Београд: Народни музеј.

Радуловић, Л., 2006

Типолошка анализа наруквица са Виминацијума, Гласник САД 22, Београд: Српско археолошко друшво, 355-374.

Raičković, A. and Milovanović, B., 2009

Rezultati istraživanja jugozapadnog dela lokaliteta Pirivoj - Viminacijum, Arheologija i prirodne nauke 5, Beograd: Centar za nove tehnologije, 7-56.

Redžić, S., 2007

Nalazi rimskih fibula na nekropolama Viminacijuma, Beograd: Centar za nove tehnologije

Schneider, B., 2005

und Edeltraud Wickum-Hover, Kleider machen Römer, Köln:
Sear, D. R., 1974

Roman coins and their values, London

Спасић, Д., 1995-96

Античка оловна огледала из Народног музеја у Пожаревцу, Viminacium 10, Пожаревац: Народни музеј Пожаревац, 29-68.

Спасић - Ђурић, Д., 2001

Рељефна огледала из Виминацијума, Viminacium 10, Пожаревац: Народни музеј Пожаревац, 159-178.

Спасић - Ђурић, Д., 2002

Виминацијум, главни град римске провинције Горње Мезије, Пожаревац: Народни музеј Пожаревац.

\section{Томовић, М., 1986}

Три мермерне главе из збирке Народног музеја у Пожаревцу, Viminacium 1, Пожаревац: Народни музеј Пожаревац, 31-41.

\section{Томовић, М., 1989/90}

Прилог проучавању камених вотивних икона са територије Виминацијума, Viminacium 4 - 5, Пожаревац: Народни музеј Пожаревац, 89-125.

\section{Томовић, М., 1991}

Проконески саркофаг са гирландама из Виминацијума, Viminacium 6, Пожаревац: Народни музеј Пожаревац, 69-81.

Tudor, D., 1959

Le dépôt de miroirs de verre doublé de plomb trouvé à Sucidava, Dacia (n.s.) 3, 415-432.

\section{Величковић, М., 1959}

Оловни оквири античких стаклених огледала из Народног музеја, Зборник радова Народног музеја 2, (1958/59), Београд: Народни музеј Београд, 55-72. 


\section{REZIME \\ RAZVOJ I PROMENE U RIMSKOJ MODI - PRIMER VIMINACIJUMA}

KLJUČne ReČI: Viminacium, NOVAC, IGLE ZA KOSU, SCULPTURE, FIBULE, OGRLICE, NAUŠNICE, NARUKVICE, PRSTENJE.

Rad je pokušaj da se uz pomoć viminacijumskog materijala napravi pregled razvoja i promena u stilu frizura i odevanju, kao i da se utvrde uticaji koje je prestonica Carstva ostavila na glavni grad provincije Gornje Mezije.

Najbrojniji materijal koji nam pruža informacije o tim promenama su srebrni i bronzani novčići. Najbolje informacije dobijaju se preko aversnih predstava rimskih carica jer se po formi njihovih frizura mogu pratiti promene u modnim trendovima. O velikoj brioju frizura govori i činjenica o preko 1700 koštanih igala i 43 češlja, otkrivena prilikom arheoloških iskopavanja.

$\mathrm{Na}$ srebrnom novcu iz perioda rimske Republike nađenom na Viminacijumu muškarci su predstavljeni sa dugom kosom, kasnija moda diktirala je kratku. Mlade devojke nosile su kosu glatko začešljanu do vrata i povezanu trakama i ukosnicama, upletenu ili vezanu u punđu. Udate rimske žene imale su podignutu kosu. Na trolisnoj elipsoidnoj kameji pronađenoj na Viminacijumu predstavljena je žena koja je po profilu i načini češljanja opredeljena kao predstava Agripine Starije. Početkom Carstva frizure su jednostavne, kosa je srednje dužine, razdeljak je na sredini i kosa pada simetrično oko lica sa ponekim uvojkom, a završava se punđom ili pletenicama.

Osim jednostavne upletene kose, veoma su česte frizure ukrašene dijademama ili velom. Faustina Senior je na kovanicama prikazivana kao sredovečna žena. Brojni novčići sa njenim portretom prikazuju je visoko začešljane kose, ukrašene biserima vezanim u venac, a ponekad je glava pokrivena velom. Julija Domna uvela je tokom prve polovine III veka nove modne trendove u načinu friziranja i nove običaje u carskom dvoru. Duga gusta kosa je razdeljena po sredini i slobodno padala na ramena, da bi se tek onda savila pozadi. Od kraja II i tokom III veka bilo je otmeno da se lice uokviri blago zatalasanom kosom koja je zatim skupljena u punđu na potiljku ili pletenicu koja se u obliku dijademe obavija oko glave. U taj period datovan je portret mlade žene, otkriven na prostoru Viminacijuma, sa karakterističnom frizurom kod koje je kosa oblikovana poput kriški dinje i po čemu je nazvana Melonen tip frizure. Na jednoj od istraživanih lokacija, na Pirivoju, nađen je i srebrni antoninijanus sa portretom Otacile. Uobičajeno je prikazivana kao mlađa ili kao zrela žena sa kosom tradicionalno raspoređenom $u$ horizontalnim pletenicama koje dopiru do vrata pa se skupljaju i podižu na teme. Salonina, šezdesetih godina III veka, praktikuje istu frizuru sa celom kosom upletenom u sitne pletenice koje se potom podižu na teme dok je niska dijadema na glavi. $\mathrm{Na}$ ovakvo predstavljanje frizura na viminacijumskom novcu nailazimo sve do carice Galerije Valerije, koja je na novcu prikazivana kao mlada žena sa ravnom začešljanom kosom i malom dijademom koja krasi glavu. Iz tog perioda su i srebrni novčić sa predstavom Konstantinove prve žene Helene i jedna fresko oslikana grobnica na Viminacijumu u kojoj je otkriven portret mlade žene izduženog lica, krupnih očiju i dugog vrata. Kestenjasta kosa koja pada do brade savijena je i zabačena unazad, a preko nje je postavljena mrežica.

Najjednostavniji oblik muške frizure dobio je naziv po caru Titu. Kosa je češljana od jedne centralne tačke na temenu prema čelu, ušima i vratu. Postojale su i maštovitije frizure koje su činili redovi uvojaka raspoređenih na razne načine da uokviruju lice. Otkriveno je nekoliko skulptura koje se po stilskim karakteristikama datuju u sredinu III veka, a sam rad se pripisuje nekoj boljoj provincijskoj radionici.

O modi na Viminacijumu svedoči i otkriće jednog olovnog sarkofaga u kojem su nađeni 
skeletni ostaci ženske osobe koja je na sebi imala lanenu košulju, a preko nje haljinu ili ogrtač od ljubičastog brokata, protkanog zlatnim nitima. $\mathrm{Na}$ nogama su bile čarape pletene od belog pamučnog konca i obuća izrađena od mrke kože. Na jednoj od otkrivenih fresaka na kojoj je mladić koji prinosi tacnu sa darovima, vidi se kako su bili obučeni mladići, a posebno lepo su predstavljene čizmice. Jedna od otkrivenih nadgrobnih stela u svom gornjem segmentu sadrži reljef koji prikazuje bračni par kome je stela i posvećena. U edikuli sa portretima na levoj strani predstavljena je žena odevena u haljinu i obmotana ogrtačem, a na desnoj je muškarac u tunici sa togom koja pada u bogatim naborima. Ženina kosa je podeljena po sredini temena i spuštena preko ušiju, a potom zavijena nisko na potiljku. Nakit na njenoj levoj ruci i ogrlica oko vrata uz ostale detalje sa stele, datuju je u vreme cara Antonija Pija.

Otkriveno je i više skulptura i nadgrobnih stela koje nam prikazuju muškarce u togama i tunikama. Među najlepšim spada i figurina od kvarcita otkrivena na prostoru amfiteatra kojoj nedostaje glava, ali se po naborima odeće vidi da je predstavljena muška osoba u tunici i dugačkoj smotanoj togi. Odeća se pridržavala različitim fibulama. One su hronološki osetljive i na svim istraživanim lokacijama nalazimo ih u velikom broju, a razvrstane su u 36 tipova, dok su tri tipa najbrojnija: 1. Fibule sa šarnirom slične Aucissa fibulama, 2. Izrazito profilisane fibule crnomorsko - podunavskog tipa i 3. Kolenaste fibule sa šarnirom.

Da su se stanovnice Viminacijuma šminkale pretpostavljamo po otkrivenoj fresci iz grobnice gde je mlada ženska osoba prikazana našminkana $i$ to sa naglašenim rumenilom na obrazima $i$ iscrtanim obrvama i trepavicama. Potvrdu za to nalazimo i u brojnim arheološkim nalazima koji se opredeljuju kao kozmetički pribor.

Za ogledanje na raspolaganju su imali i različita ogledala. Koristili su ručna, zidna, stona, kao i ogledala sa poklopcem ili ogledala na toaletnim kovčezima.
Najluksuzinija ogledala pronađena su $\mathrm{u}$ južnim viminacijumskim nekropolama i na njima su reljefne predstave sa mitološkim scenama.U velikom broju javljaju se i staklena ogledala sa olovnim okvirom.

Nakit se osim metala, izrađivao od dragog kamenja, kosti, staklene paste i gagata. Omiljena forma nakita kod Rimljana su ogrlice od dvostruko ili višestruko upletenih lanaca omčastog tipa. Privesci su obično krasili ogrlice, ali ima slučajeva gde su otkriveni na narukvicama. Uglavnom su izrađivani od metala u kombinaciji sa dragim kamenjem, mada nailazimo i na primerke od kosti i staklene paste. Veliki broj primeraka privezaka medaljona nađenih na Viminacijumu omogućava nam da ovde lociramo radionicu za produkciju kameja i gema.

Pored ogrlica, naušnice predstavljaju omiljeni tip nakita kod Rimljanki. Naušnice sa Viminacijuma mogu se razvrstati u XIII tipova sa brojnim varijantama i podvarijantama. Osnovna podela naušinica zasniva se na principu zakopčavanja, tako da se razlikuju naušnice tipa karičice (otvorenih ili zatvorenih krajeva) i one sa tzv. „S“ kukicom za fiksiranje.

Osim estetske uloge, narukvice su imale posebnu ulogu u vojsci jer su pored torkvesa i falera imale funkciju vojničkih insignija. Izrađivane su od metala, staklene paste, gagata i kosti. Podeljene su u dve osnovne grupe: narukvice zatvorenih i otvorenih krajeva. Najranije narukvice na našim prostorima su od srebra $i$ bronze prevučenih i spiralno namotanih krajeva. Narukvice koje se zatvaraju kukicom i petljom različito su ukrašene. Izrađene su od glatke ili upletene žice, a datovane su u III i IV vek. Najbrojnije i najraznovrsnije su narukvice otvorenog tipa čiji su krajevi ukrašeni urezima, prošireni ili suženi ili se završavaju zmijskim glavama.

U doba Republike nošeno je gvozdeno prstenje, dok je zlatno bilo odlika dostojanstva. Forma prstena je zavisila od njegove namene. Prstenje istog oblika izrađivano je uglavnom od 
različite vrste metala i ukrašavano urezivanjem različitih motiva ili umetanjem paste ili dragog kamenja. Često je prsten imao glavu sa ufasovanom gemom ili ređe kamejom. Navedene primerke možemo ispratiti prikazom pojedinih tipova sa Viminacijuma. Jeftiniji primerci umesto dragog kamena imali su ufasovanu staklenu pastu. Osim pečatnog, postojalo je vereničko prstenje koje se nije bitno razlikovalo od ostalog prstenja.

Očekujemo da će buduća iskopavanja pružiti još lepše nalaze koji će Viminacijum potvrditi ne samo kao radioničarski centar više zanata, nego i kao grad u kom su stanovnici negovali i imali smisao za lepo. 